\title{
VIRUS DO MOSAICO DAS NERVURAS DA VIDEIRA NO ESTADO DE SÃO PAULO
}

HUGO KUNIYUKI

Engenheiro Agrônomo

Orientador: Dr. ÁLVARO SANTOS COSTA

Tese apresentada à Escola Superior de Agricultura "Luiz de Queiroz", da Universidade de São Paulo, para obtenção do título de Doutor em Agronomia, Area de Concentração: Fitopatologia 
Kuniyuki, Hugo

K96v

Vírus do mosaico das nervuras da videira no Estado de São Paulo. Piracicaba, 1988.

96p. ilus.

Tese - ESALQ

Bibliografia.

1. Mosaico das nervuras em uva - São Paulo (Estado) 2. Uva - Doença - São Paulo (Estado) 3. Virose vegetal - São Paulo (Estado) 4. Vírus fitopatogênico - São Paulo (Estado) I. Escola Superior de Agricultura Luiz de Queiroz, Piraci caba

$\operatorname{CDD} \quad 634.828$ 


\section{VIRUS DO MOSAICO DAS NERVURAS DA VIDEIRA \\ NO ESTADO DE SÃO PAULO}

HUGO KUNIYUKI

Aprovada em: 02.03 .89

Comissão julgadora:

Prof. Dr. DARCY MARTINS DA SILVA

ESALQ / USP

Prof. Dr. HIROSHI KIMATI

ESALQ /USP

Prof. Dr. VLADIMIR RODRIGUES SAMPAIO

ESALQ / USP

Dr. ÁLVARO SANTOS COSTA

IAC

Dr. GERD WALTER. MULLER

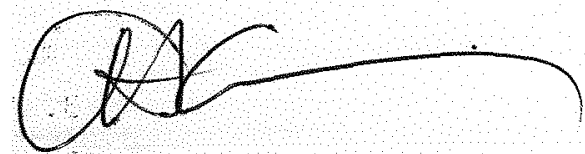

Dr. ÁLVARO SANTOS COSTA

orientador 
iii.

A minha esposa e

à memōria de minha mãe,

D E D I C C 


\section{A GRA DE CI HENTOS}

o autor deseja expressar os seus sinceros agra decimentos:

- ao Dr. Alvaro Santos Costa, orientador, pe1o incentivo, discussões, sugestöes e críticas estimulantes, durante o desenvolvimento do trabalho e também, pela revisão dos originais;

- aos pesquisadores científicos Fernando P. Martins e Hélio S. scaranari (Estaçäo Experimental de Jundiaí), Maurilo M. Terra e Erasmo J. P. Pires (Seção de Viticultura) e Ivan J.A. Ribeiro (Seção de Microbiologia Fitotéc nica), do Instituto Agronômico de Campinas, pela colaboração prestada;

- ao engenheiro agrônomo Antonio Y. Kishino, do Instituto Agronômico do Paraná, Londrina, PR., pelo auxí1 i prestado;

- aos colegas da Seção de Virologia do Instituto Agronômico de Campinas, pelo apoio e sugestóes apresentados durante o desenvolvimento deste trabalho;

- aos funcionários da seção de Virologia que, de al guma forma, contribuíram para a realização deste traba1ho;

- ao CNPq (Conselho Nacional de Desenvolvimen to Científico e Tecnológico) pela concessäo de bolsa de pesquisa;

- ao Instituto Agronômico de Campinas, pela oportunidade de aperfeiçoamento. 
SUMAERIO

Pàgina

LISTA DE FIGURAS $\ldots \ldots \ldots \ldots \ldots \ldots \ldots \ldots \ldots \ldots \ldots \ldots \ldots \ldots \ldots \ldots$



RESUMO $\ldots \ldots \ldots \ldots \ldots \ldots \ldots \ldots \ldots \ldots \ldots \ldots \ldots \ldots \ldots \ldots \ldots \ldots \ldots \ldots \ldots \ldots \ldots$

SUMMARY $\ldots \ldots \ldots \ldots \ldots \ldots \ldots \ldots \ldots \ldots \ldots \ldots \ldots \ldots \ldots \ldots$ Xiv

1 INTRODUÇÃO $\ldots \ldots \ldots \ldots \ldots \ldots \ldots \ldots \ldots \ldots \ldots \ldots \ldots \ldots \ldots \ldots$

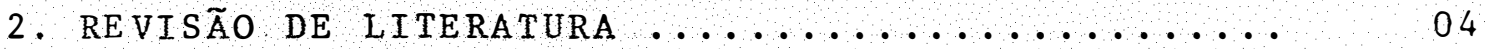

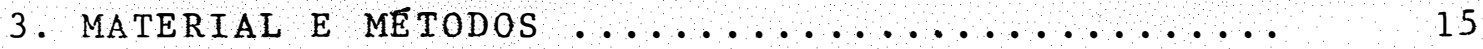

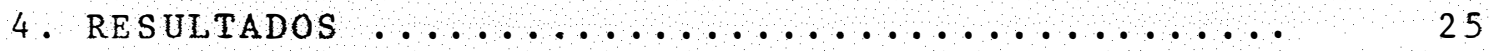



4.1.1. Avaliação da incidência em São Pau$10 \ldots \ldots \ldots \ldots \ldots \ldots \ldots \ldots \ldots \ldots \ldots \ldots$

4.1.2. Incidência em amostras procedentes de outros estados do Brasil ........

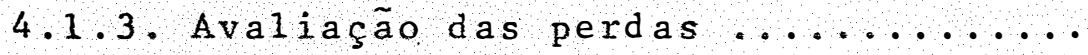

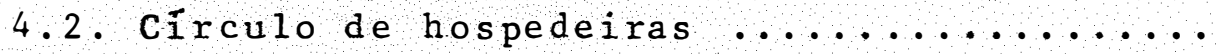

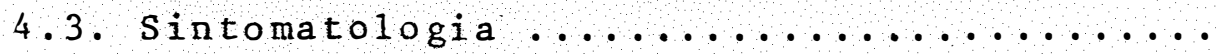

4.3.1. Sintomas do mosaico das nervuras em variedades de copa ............. 36

4.3.2. Sintomas do mosaico das nervuras em porta-enxertos .............

4.3.3. Anomalias de outras causas com sintomas semelhantes aos da virose mo-

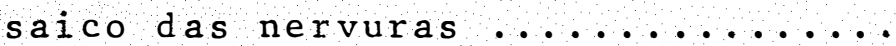

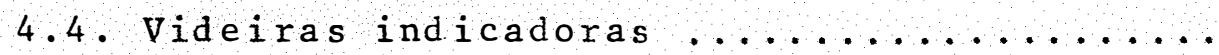


4.4.1. Comparação de videiras ina i cadoras infetadas por 3 isolados do vírus do mosaico das nervuras e mantidas dentro e fora de casa de ve getação

4.4.2. Outros fatores que podem influir na manifestação de sintomas em indica doras mantidas ou colocadas forade cas a de vegetação ..............

4.4.3. Tentativas visando induzir o apare cimento de sintomas do mosaico das nervuras nas indicadoras após a bro tação de primavera .............

4.5.Etiologia .....................

4.5.1. Perpetuação ................

4.5.2. Transmissibilidade

4.5.2.1. Transmissão por união de tecidos .............

4.5.2.2. Ligações com cus cuta....

4.5.2.3. Tentativas de inoculação mecânica..............

4.5.2.4. Transmissão pela semente.

4.5 .2 .5 . Vetor ...............

4.5.3. Tentativas de visualização de partículas semelhantes a vírus ao microscópio electrônico ...........

4.5.4. Isolados do vírus do mosaico das nervuras ...................

4.5.4.1. Isolados das variedades Kioho e 01 impia .........

4.5 .4 .2 . I sol ado fraco do vírus do mosaico das nervuras obti do da variedade Itälia... 
vii.

Pàgina

4.6. Controle ............................. 64

4.6 .1 . Inde xação .................... 65

4.6 .2 . Medidas curativas ............. 65

4.6 .2 .1 . Termoterapia .......... 65

4.6 .2 .2$. Microenxertia ......... 67

5, DISCUSSÃO $\ldots \ldots \ldots \ldots \ldots \ldots \ldots \ldots \ldots \ldots \ldots$

6. CONCLUSÕES ..........................

REFERENCIAS BIBLIOGRAFICAS .................. 84 
Porcentagem de infecção pelo vírus do mosaico das nervuras em amostras das princi pais variedades de copa de videira cultivadas ou mantidas em coleção em são paulo .....

Porcentagem de infeç̧ão pelo vírus do mosaico das nervuras em amostras de 12 variedades de copa procedentes de importan tes regiões vitícolas do Estado de São Pau $10 \ldots \ldots . \ldots \ldots \ldots \ldots \ldots \ldots \ldots \ldots \ldots \ldots \ldots \ldots$

Porcentagem de infecção pelo vírus do mosaico das nervuras em amostras de plantas matrizes dos principais porta-enxertos de videira utilizados ou mantidos em coleção em São Paulo ...................

Porcentagem de infecção pelo vîrus do mosaico das nervuras em material propagati vo de 5 porta-enxertos coletado de planta f̧ões comerciais ....................

Incidência do vírus do mosaico das nervuras em material propagativo de videira pro cedente de outros estados do Brasil .....

Re ação apresentada por plantas de diferen tes variedades e híbridos de Vitis inoculados com o vírus do mosaico das nervuras e recuperação para videira ind icadora Rupestris du Lot ..................... 
7 Reações apresentadas pelas variedades ltá I ia, LN-33 e Rupestris du Lot às infecçoes mistas do vírus do mosaico das nervuras comoutros vírus constatados em Säo Pau$10 \ldots \ldots \ldots \ldots \ldots \ldots \ldots \ldots \ldots \ldots \ldots \ldots \ldots \ldots \ldots$

8 Visualização de sintomas em videiras indi cadoras infetadas por 3 isolados do vírus do mosaico das nervuras e mantidas dentro e fora de casa de vegetação ........

9 Efeito de diferentes ambientes no apareci mento de sintomas do mosaico das nervuras nos novos crescimentos das videiras indicadoras após a brotação de primavera ....

10 Transmissão do vírus do mosaico das nervu ras pela enxertia de gema de plantas infe tadas de diferentes variedades de videira em 3 porta-ensertos que exibem sintomas da moléstia ...................

11 Influência dos métodos de enxertia na manifestação dos sintomas do mosaico das nervuras na videira indicadora Rupestris d u Lot ..........................

12 Inoculação por enxertia dos vírus do mosaico das nervuras de Kioho e $01 \dot{i} \mathrm{mpia}$ e recuperação para videira indicadora Rupes

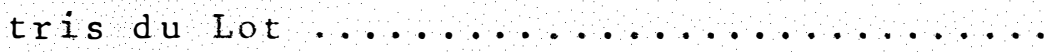


13 Inoculação por enxertia dos isolados comuns e de kioho do vírus do mosaico das nervuras em variedades de copa e de porta-enxerto e recuperação para videira indicadora Rupestris du Lot..............

14 Reações obtidas nos testes de proteção para verificar a relação entre os isolados comuns e os de kioho e 01 impia do vírus do mosaico das nervuras ............ 


\section{VIRUS DO MOSAICO DAS NERVURAS DA VIDEIRA NO ESTADO DE SÃO PAULO}

Autor: HUGO KUNIYUKI

Orientador: Dr. ALVARO SANTOS COSTA

\section{RESUMO}

o presente trabalho teve por objetivo ampliar os conhecimentos sobre a virose denominada mosaico das nervuras que ocorre nos vinhedos do Estado de são paulo, com ênfase em aspectos referentes à sintomatologia, etiologia, epidemiologia e controle.

Os experimentos foram conduzidos nos laboratórios de patologia, microscopia electrônica e cultura de tecidos e nas casas de vegetação e canteiros da seção de virologia do Instituto Agronômico de Campinas.. 0 material propa gativo utilizado nos experimentos foi de diferentes variedades de copa e de porta-enxerto de videira, cultivadas ou man tidas nas principais regióes vitícolas do Estado.

Evidências obtidas através da sintomatologia em indicadoras comprovaram que o vírus do mosaico das nervuras que ocorre em São Paulo é idêntico ao vírus da "grapevine fleck disease" que ocorre em outros países. o vírus foi também registrado em material procedente de Goiás, Minas Gerais, Paraná, Rio Grande do Sul e Santa Catarina. No Estado de São Paulo, testes de indexação feitos em 44 variedades de copa demonstraram que 12 , entre as quais a Itália e Itália Rubi, achavam-se $100 \%$ infectadas; as outras 32 apresentaram porcentagens de infecaó entre 17 e $87 \%$. Dos 19 porta-enxertos, 7 apresentaram-se 1 ivres do vírus e 12 com incidências entre 12 e $75 \%$. 
o vírus do mosaico das nervuras foi facilmente transmitido e recuperado por união de tecidos, mas nào passou pela semente, por inoculação mecânica e por cuscuta. As evidências sobre a existência de vetor foram negativas. Concluiu-se. que a ocorrência do vírus resulta de sua perpetuação através da propagação vegetativa de plantas infectadas de copa e de porta-enxerto de videira. Não foi observada partícula viral ao microscópio electrônico que pudesse ser associada a doença. Foram registrados 3 isolados diferentes pertencentes ao complexo do vírus do mosaico das nervuras; nas interaçóes entre 2 deles (isolados comuns e os de Kioho e olimpia) foram observados os fenómenos da proteção e da supressão.

A grande maioria das variedades de copa não mostrou sintomas de infecção; dos porta-enxertos, apenas 3 (Golia, kober 5BB e Rupestris du Lot) foram capazes de os exibir de maneiranítida, os quais consistiram de palidez das nervuras menores das folhas jovens e médies da brotação de primavera. Tornou-se indispensável o emprego de videiras in dicadoras para a diagnose da moléstia, sendo determinado que o porta-enxerto Rupestris du Lot é o mais indicado para essa finalidade. 0 kober $5 \mathrm{BB}$ deve ser incluído nos testes de identificação dos isolados do vírus.

0 mosaico das nervuras pode ser facilmente con trol ado através do emprego de material propagativo sadio. Clones livres de vírus de variedades de copa e de porta-enxerto d.e importância para a viticultura de são paulo e de outras áreas do país foram conseguidos através de testes de indexa ção e de termoterapia. Coleção de plantas matrizes sadias dessas videiras foi organizada no Instituto Agronômico de Campinas, para fornecimento de material propagativo aos interessados. 


\title{
GRAPEVINE FLECK VIRUS IN THE STATE OF SÃO PAULO
}

\author{
Author: HUGO KUNIYUKI \\ Adviser: Dr. ÁLVARO SANTOS COSTA
}

\section{SUMMARY}

The present investigation was undertaken with the purpose of obtaining more information on a virus disease named "mosaico das nervuras" (grapevine fleck disease), that occurs in vineyards of the state of são Paulo, Brazil, with emphasis on aspects concerning symptomatology, etiology, epidemiology and control.

The experiments were carried out at the Virus Department of the Instituto Agronomico, Campinas, SP. The propagative material used in the studies was from different scion and rootstock varieties cultivated in the most important grape-growing areas of the state.

Symptoms on the indicator plants showed that the "mosaico das nervuras" is a disease induced by the grape vine fleck virus, that occurs in other grape-growing coun tries. The virus was a 1 so detected in propagative material from the states of Goiás, Minas Gerais, Paranā, Rio Grande do sul and Santa Catarina. In the state of são paulo, results of indexing tests to indicator p 1 ants showed that 12 scion varieties, including Italia and Italia Ruby, were 100\% infected with the virus and 32 others were infected in percentages varying from 17 to $87 \%$. . of the 19 rootstock varieties tested, 7 were free of the virus and 12 were infected, with incidence of 12 to $75 \%$ 
The grapevine fleck virus was easily transmitted and recovered by tissue union; it was not transmitted by seed, by mechanical inoculation and by a species of cuscuta that grows under são paulo conditions. There is also no evidence for the existence of a vector. Thus, the principal cause of the presence of the disease in the vineyards is the perpetuation of the virus through the vegetative propagation of infected plants. No virus particles were observed under the electron microscopy that could be associated to the disease. Three different isolates of the grapevine fleck virus complex werefound in São Paulo. The phenomena of protection and suppression were verified in the interaction between 2 isolates of the virus.

Most scion and rootstock varieties were symptom less when infected by the virus; 3 rootstocks (Golia, kober $5 \mathrm{BB}$ and Rupestris du Lot) showed typical symptoms, that consist of clearing in the third and fourth order veins of the young and medium-aged leaves of the spring growth. Thus, tests on indicator varieties are necessary for identification of the disease in most cases. The rootstock Rupestris du Lot is a good indicator for the grapevine fleck disease under São paulo conditions; it is important to use the rootstock kober $5 B B$ in identification tests of the virus isolates.

Control of the grapevine fleck disease can be easily accomplished by use of virus-free stocks. Healthy clones of the most important scion and rootstock varieties cultivated in são Paulo and other grape-growing. areas of Brasil were found by indexing to indicator varieties or obtained by heat treatment. Virus-free foundation stock of these grapevines was established at the Instituto Agronomico to provide propagative material to growers and nursery men. 


\section{INTRODUCÃO}

A cultura da videira (vitis spp.) representa uma das mais importantes produçóes frutíferas do Brasil, cons tituindo-se em uma atividade de considerável expressão sócio económica. No ano agrícola de 1986/87, a área colhida foi de 58.483 hectares e a produção de uvas de mesa e para vinho foi de 589.483 tone 1 adas (ANUARIO ESTATISTICO DO BRASIL, 1986). No Estado de São Paulo, para o ano agrícola de $1987 / 88$, foi estimada uma ārea de cerca de 8.900 hectares, uma população em torno de 38 milhóes de videiras e uma produção aproximada de 92.000 tone 1 adas de uva de mesa e 11.500 toneladas de uvas para vinho (INFORMAÇÕES E CONOMICAS 3/88). Na safra de $1986 / 87$, a uva de mesa atingiu o valor de 801 milhões de cru $z$ ados (PROGNÓSTICO 1987/88).

A viticultura paulista caracteriza-se pelo cul tivo de variedades americanas de uvas comuns de mesa e para vinho, viniferas produtoras de uvas finas de mesa e híbridos franceses para vinho. Algumas variedades criadas por hibridação e selecionadas no Instituto Agronómico de Campinas tam bém estão sendo plantadas nas principais äreas vitícolas do Estado para produção de uvas de mesa e para vinho (SANTOS NETO, 1969 ; PEREIRA \& MARTINS, 1972 e OJIMA et alii, 1984).

Apesar da importáncia representada por essa atividade, sabe-se, desde longa data, que existe uma série 
de problemas que afetam o vigor e a longevidade das plantas, diminuem a produção quantitativa e qualitativamente e reduzem a cotação da uva no mercado. Em um diagnóstico da situa ção atual da cultura em São Paulo, al guns fatores de nature$z$ a cultural e fitossanitaria foram enumerados como os causadores desses problemas. E um dos fatores mencionados tem si do o uso de material propagativo infetado por viroses (OJIMA et a $1 \mathrm{ii}, 1984$ ).

Segundo investigações feitas na seção de Viro logia do Instituto Agronómico de Campinas, já é conhecida a ocorréncia de 5 viroses distintas nos vinhedos paulistas (KUNIYUKI, 1981), Sob o ponto de vista da Virologia Vegetal, is so, contudo, não constitui novidade, pois os atuais clones da maioria das variedades de copa e de porta enxerto planta das em Sáo Paulo e no resto do país resultam da multiplica ção de material propagativo introduzido há longos anos de países que hoje enfrentam sérios problemas com moléstias de vírus.

Dentre os vírus registrados em são Paulo, o do mosaico das nervuras (KUNIYUKI, 1976) tem-se destacado pe la frequência com que tem sido detectado nas plantações de uva. Esse vírus é considerado semelhante ao da "grapevine fleck diasease" descrita por HEWITT et alii (1972). Muitos aspectos referentes ao mosaico das nervuras ainda não são su ficientemente conhecidos no Brasil, tornando interessante a obtenção de maiores informaçóes acerca da sintomatologia, etio logia, epidemiologia e controle e da situaçäo em que se encontra a viticultura paulista no tocante a essa moléstia.

o presente trabalho aborda as investigaçóes feitas em que se procurou acumular conhecimentos sobre o mosaico das nervuras em São paulo, principalmente na área de pato logia e, ao mesmo tempo, oferecer elementosque auxiliassem de 
maneira positiva na solução dos problemas que existem nos vi nhedos paulistas. 


\section{REVISÃO DE LITERATURA}

A moléstia da videira conhecida por mosaico das nervuras foi constatada pela primeira vez por HEWITT et ali i (1962) nos Estados Unidos. Esses pesquisadores derama denominação de "grapevine fleck disease" devido aos sintomas de palidez de pequenos comprimentos das nervuras menores das folhas de videira Rupestris du Lot, passando esse nome a ser adotado na língua inglesa. Em trabalho posterior, HEWITT et alii (1972) demonstraram experimentalmente a transmissibilidade da moléstia por uniāo de tecidos e com base nesse resul tado, consideram-na ser causada por um vírus. Essa virose tem recebido outros nomes, como "marbrure" na Franca (VUITTENEZ, 1966), "jaspeado clorótico latente" na Espanha (PE NAIGLESIAS, 1978), "maculatura infettiva" na Itália (TRIOLO\& MATERAZZI, 1987) e "marmoreado" em Portugal (PEDROS0, 1987).

Desde o registro da moléstia feito em 1962 até o presente, o vírus do mosaico das nervuras já foi assinalado em diversos outros países, tais como na frança (VUITTENEZ, 1966 e 1970), Austrälia (McGECHAN, 1970), África do Sul (ENGELBRECHT \& NEL, 1971 ), Suiça (BOVEY, 1972 a), Espanha (PE NAIGLESTAS \& AYUSO, 1973), UCrania, URSS (SHTERENBERG et a lii, 1973), Brasil (KUNIYUKI, 1976), Itälia (REFATTI \& GRANATA, 1980), Japão (TERAI \& YANO, 1980), Moldavia, URSS (VERDEREVSKAJA et alii, 1983) e Portugal (PEDROSO, 1987). Segundo MAR TELLI (1986), o mosaico das nervuras tem sido comumente registrado em diversos países do Mediterräneo (Argélia, Chipre, 
Israel, Jordânia, Tunisia e Turquia). Nos Estados Unidos, KAHN et alii (1979) detectaram o virus do mosaico das nervuras através de testes de indexação em material propagativo intro duzido de 18 paises, como a Alemanha, Argentina, India, Irá, Inglaterra, Líbano, México, Nova Zelándia, além de alguns ou tros já mencionados como o Brasil. o mosaico das nervuras fol incluído dentro do grupo das viroses da videira que sáo de distribuição mundial (GOHEEN, 1977; UYEMOTO et alii, 1978; BOVEY et alii, 1980 e MARTELLI, 1986).

0 mosaico das nervuras ocorre com frequência variável nos principais países vitícolas. Nos Estados Unidos, o vírus tem sido recuperado de numerosas variedades cul tivadas em diferentes áreas da Califórnia (HEWITT et alii, 1962). Na Fraņa, VUITTENEZ (1970) verificou que $20 \%$ das 304 plantas selecionadas anteriormente como sadias encontravam-se infetadas, sendo que a variedade Chasselas achava - se com porcentagem de infecção de $40 \%$. Em amostras das varieda des Chasselas e Cardinal de plantaçöes comerciais, . BoUBALs (1971) determinou níveis de infecção de 95 e $100 \%$, respectivamente. Ainda na França, VALAT (1972) verificou que 18 dos 29 clones de 9 variedades de mesa e 16 das 66 plantas de variedades de vinho, considerados sadios, estavam infetados pe 10 vírus; os 12 porta-enxertos testados estavam 1 ivres do ví rus. Na Itälia, entre 22 variedades de V. vinlfera testadas, 11 encontravam-se infetadas; o vírus também foi detecta do em plantas matrizes de 3 porta-enxertos (REFATTI \& GRANATA, 1980). Na Äfrica do Sul (NEL \& ENGELBRECHT, 1972) e na Espanha (PENA-IGLESIAS \& AYUSO, 1973), o mosaico das nervuras tem sido detectado de maneira generalizada nas variedades de copa e de porta-enxerto cultivadas nesses países.N Na Austrälia, McGECHAN (1970) assinala que o vírus está presente em todas as plantaçóes de videira nas quais são empregados os porta-enxertos Rupestris du Lot e $420 \mathrm{~A}$, mas Woodham et a 1 i (1973) afirmam que esse patógeno tem sido raro nas vi- 
deiras submetidas a testes de inderação. Na Ucrania (URSS), foi comprovado que o vírus do mosaico das nervuras ocorre com incidência de $70 \%$ nas variedades locais e que 9 das 15 varie dades européi as achavam-se infetadas com incidência de $55 \%$ (SHTERENBERG et alii, 1973). Na Repüblica da Moldavia (URSS), em teste de 2.000 plantas de numerosas variedades, $37,6 \%$ das videiras de copa e $8,6 \%$ de cavalos encontravam-se infetados (VERDEREVSKAJA et ali i, 1983). No Japão, $42 \%$ das 53 plantas indexadas da variedade koshu indicaramestar infetadas pelo vírus do mosaico das nervuras (TERAI \& YANO, 1980).

Não existem ainda muitas informações acerca da importância do mosaico das nervuras em relação às perdas quantitativas e qualitativas. RIVES, citado por BOUBALS (1971), que não menciona a fonte de informação, estima que a moléstia reduz o rendimento de 6 a $7 \%$ na variedade chasselas. No Japão, ocorre uma moléstia denominada "ajinashika" ("teste less" na língua inglesa), que se caracteriza por causar gran de reduçáo no teor de açūcar dos frutos e que é considerada ser induzida pelo vírus do mosaico das nervuras ou então, pe la combinação desse vírus com o do enrolamento da folha; nas variedades koshu e Bacco $22 \mathrm{~A}$, os frutos de videira com "ajinashika" apresentam teor de açücar de 10 a $140 \mathrm{Brix}$ em comparação com os de plantas aparentemente normais, que mostram de 17 a $220 \mathrm{BriX}$ (TERAI \& YANO, 1980 e 1985).

Apesar desses fatos, nem todos concordam em considerar a moléstia como sendo de importância económica. HUGLIN, também mencionado por BOUBALS (1971), selecionou um clone da variedade GewUrztraminer que, embora infetado pelo vírus, tem-se mostrado bastante interessante pela sua produtividade. Caso semelhante foi observado por BovEY (1972a) com clones da variedade Chasselas. Assim sendo, BOVEY et a li ( 1980 ) colocam o vírus do mosaico das nervuras dentro do grupo dos vírus da videira que têm bai xa patogenicidade e re 
duzida importáncia econômica. GOHEEN (198) também acha que - vírus não causa ou causa pouco dano à produção de uva. Embora as informações sobre a importāncia da moléstia sejam ainda es cassas, a França, através da Associação Nacional para o Melhoramento Técnico da Videira, inclui o virus do mosaico das nervuras como um dos 3 vírus (juntamente com os do enrolamen to da folha e o da folha em leque) que devem ser detectados nos testes de indexação do material propagativo de videira (HUGLIN et ali , 1980).

Segundo HEWITT et alii (1962 e 1972) e VUITTENEZ (1970), os sintomas característicos do mosaico das ner vuras são observados em plantas infetadas do porta - enxerto Rupestris du Lot, também conhecido por st. George. Consistem de palidez das nervuras menores, geralmente das terciárias e quaternärias, das folhas jovens e médias. o nünero dessas man chas de pequenos comprimentos é bastante variável, de uma a vârias. Folhas com sintomas intensos são onduladas e distorcidas e muitas delas, com os bordos virados para cima. De acordo com alguns autores (MCGECHAN, 1970; HEVIN et alii, 1973 a , VUITTENEZ, 1978 e WATANABE et alii, 1986), os sintomas foliares são restritos aos crescimentos feitos em climas amenos na primavera e no outono. As plantas afetadas de Rupestris du Lot apresentam um porte mais compacto e o vigor é reduzido (VUITTENEZ, 1970 ; SCHTERENBERG et alii, 1973 e REFATTI \& GRANATA, 1980 ).

Além do porta-enxerto Rupestris du Lot, poucas videiras têm sido listadas como apresentando sintomas. Se gundo VUITTENEZ $(1970$ e 1978), o vírus afeta severamente $V$. rupestris e alguns poucos híbridos de V. rupestris com V.ber landieri, como o 99R. NEL \& ENGELBRECHT (1972) também obser varam grande reduçáo de vigor do porta-enxerto $99 \mathrm{R}$ quando in fetado pelo vírus. Hä menção de que os porta-enxertos 5 C (BOVEY, 1972a) e Teleki J-1-6-14 (CORBETT \& WIID, 1985) tam- 
bém exibem sintomas da moléstia. A reação observada por diferentes autores quanto ao porta-enxerto kober $5 B B$ não tem sido concordante. HEWITT et alii (1972) e BOVEY (1972a) observaram reações em plantas inoculadas desse cavalo, semeIhantes às presentes em Rupestris du Lot, mas esse tipo de sintoma não foi notado por LEGIN \& VUITTENEZ (1973), REFATTI et alii (1978) e REFATTI \& GRANATA (1980). Segundo LEGIN \& VUITTENEZ (1973), as reaçoes apresentadas por Kober $5 B B$ seriam induzidas por um outro vírus causador de uma moléstia denominada "mosaique des nervures" ou "vein mosaic" que exis te na Europa e que costuma ocorrer juntamente com o "grapevine fleck disease" em muitas variedades. A grande maioria das variedades de copa e de porta-enxerto de importância eco nómica nos diversos países não mostra sintomas visíveis quan do infetada pelo vírus causador do mosaico das nervuras ( $\mathrm{HE}$ WITT et alii, 1972; BOVEY et a1ii, 1980 e MARTELLI, 1986).

Diferentes vírus podem infetar simultaneamen te as videiras, mas a formação de complexos no sentido de al teraçóes sintomatológicas ou sinergismo ainda não foi observada. Na literatura especializada, é bastante comum encontrar referências sobre a ocorrência do vírus do mosaico das nervuras infetando as videiras em combinações com outros vírus, sem contudo, causar mudanças nas reações ou no desenvol vimento vegetativo devido a interaçoes entre esses agentes (VUITTNEZ, 1970, ENGELBRECHT \& NEL, 1971 ; HEWITT et alii, 1972 ; LEGIN, 1972 ; WOODHAM et alii, 1973; PEÑA-INGLESIAS \& AYUSO, 1973 e KRAKE \& WOODHAM, 1978). Contudo, SHTERENBERG et ali (1973) notaram que a videira indicadora Rupestris du Lot, quando infetada pelos vírus do mosaico das nervuras e do mosaico amarelo da fol ha em leque, exibe uma coloração ama relada nas nervuras terciárias e quaternárias e tecidos adja centes. NEL \& ENGELBRECHT (1972) verificaram grande redução no vigor da combinação copa-cavalo de certas variedades, quan do infetada simultaneamente pelos vírus do mosaico das nervu 
ras e enrolamento da folha. TERAI \& YANO (1985) observaram que plantas da variedade Baco $22 \mathrm{~A}$ apresentaram maior redução no teor de açücar dos frutos, quando infetadas simultaneamen te pelos virus do mosaico das nervuras e do enrolamento da folha, do que quando infetadas isoladamente.

Sintomas de palidez das nervuras em videira não são devidos apenas ao vírus do mosaico das nervuras. BoVEY et alii (1980) menciona a ocorrência de uma anomalia de natureza genética que induz sintomas de clareamento das nervuras muito semelhantes àqueles do mosaico das nervuras em al gumas variedades, como a Chasselas.

os efeitos da infecção causada pelo vírus do mosaico das nervuras sobre os processos fisiológicos da plan ta são muito pouco conhecidos. A única menção é a feita por TERAI \& YANO (1980 e 1985) de que os frutos de videira com "ajinashika" apresentam menor teor de açúcar do que os das sadias. Em estudos an atómicos, VUITTENEZ (1970) e BOVEY ( 1972 a) não conseguiram encontrar trabéculas nos ramos de plantas infetadas por esse vírus. Necrose dos tecidos do floema foram observadas em material de videira com "ajinashi ka" (NAMBA et alii, 1979).

A diagnose do mosaico das nervuras só tem sido feita através da observação de sintomas característicos na videira indicadora Rupestris du Lot, a qual vem sendo empregada por todos os pesquisadores que investigam essa moléstia. Além disso, esse porta-enxerto é também indicadora de alguns outros vírus da videira (MARTELLI, 1986). A diagnose da virose consiste portanto em enxertar plantas de Rupestris du Lot com material propagativo de videira cujo estado de sanidade se quer determinar.

A transmissão do vírus por união de tecidos 
tem sido feita por diferentes técnicas de enxertia, seja em estado herbáceo ou dormente, sendo que a mais empregada é a borbulhia em placa ("chip budding"), por ser a mais facil de executar em larga escala (HEWITT et alii, 1972; VAlAT, 1972; VUITTENEZ, 1973 ; BOVEY et alii, 1974 e REFATTI \& GRANATA, 1980). o tempo para obtenção de resultados tem sido variável, de 2 a 3 meses até 24 meses. De modo geral, a enxertia é feita durante a primavera e veráo de um ano e a leitura dos sintomas durante a primavera do ano seguinte.

Devido ao longo tempo demandado para o aparecimento de sintomas nas videiras indicadoras inoculadas experimentalmente, investigações vêm sendo feitas no sentido de encurtar esse período. HEVIN et alii (1973a) adotarama técnica da enxertia em ramos verdes no verão e conseguiram observar sintomas em plantas de Rupestris du Lot mantidas em solução hidropônica depois de 20 a 30 dias da inoculação. Ado tando também a técnica da enxertia verde em fins de primave ra, WATANABE et alii (1986) conseguiram notar sintomas fracos da moléstia em plantas de Rupestris du Lot mantidas em campo e no telado decorridos 14 a 23 dias da enxertia. MINK \& PARTONS (1977) verificaram que a expressão dos sintomas do mosaico das nervuras ocorreu de maneira nitida 40 dias depois que plantas já infetadas da indicadora Rupestris du Lot foram colocadas em cámara de crescimento a $220 \mathrm{C}$ e sob 24 horas de luz. Quando as plantas foram submetidas a um "precon dicionamento" a $320 \mathrm{C}$ durante 9 dias, sintomas evidentes foram observados aos $15 \mathrm{di}$ as de exposição a $220 \mathrm{C}$.

Tentativas vêm sendo feitas no sentido de caracterizar o vírus do mosaico das nervuras. Até o presente, as suas propriedades físicas e bioquímicas e relaçóes sero10 gicas não são conhecidas. Em exames ao microscópio electrônico das células companheiras e de parénquima do floema de folhas e frutos de plantas com "ajinashikall da variedade ko- 
shu, NAMA et alii (1979) observaram particulas de $28 \mathrm{~nm}$ de diàmetro. VERDEREVSKAJA et alii (1983) notaram partículas isométricas de 23 a $30 \mathrm{~nm}$ de diámetro em agregados arciformes ou circulares rodeados por uma membrana dupla em células companheiras do floema de folhas de videira infetada. Mais recentemente, NAMBA et alii (1986) voltaram a observar partí culas isométricas limitadas ao floema, de $25 \mathrm{~nm}$ de diámetro, em videira com "ajinashika",. Por outro 1 ado, CoRBETT \& WIID (1985) não conseguiram notar partículas semelhantes a vírus em extratos de pecíolos, casca dos entre-nós e fol has novas de videiras que exibiam sintomas típicos do mosaico das nervuras. A existéncia de isolados fracos e fortes do complexo do vírus do mosaico das nervuras é também conhecida, com base na intensidade de sintomas na indicadora Rupestris du LOL (TRIOLO \& MATERAZZI, 1987).

A possibilidade de o mosaico das nervuras ser de origem procariótica foi descartada por TRIOLO \& RESTA (1985), pois obtiveram resultados negativos nos testes de aplicação de antibióticos a base de tetraciclina e nos testes citológicos baseados no corante de Dienes.

0 a gente causa 1 do mosaico das nervuras indica ter certa resisténcia ao calor. Com base na termoterapia, RIVES (1972) conclui u que o mosaico amarelo do complexo da folha em leque ("grapevine fanleaf") e o mosaico das nervuras eram causados por vírus diferentes, pois cultivando p 1 an tas da variedade sémillon simultaneamente infetadas pelos 2 agentes a $370 \mathrm{C}$ durante 3 meses, verificou que suas propagaçóes estavam livres do primeiro, mas não do segundo vírus. GOHEEN \& LUHN (1973) e GOHEEN (1977) incluem o agente do mosaico das nervuras dentro do grupo de vírus moderadamente es táveis in vivo à temperatura de $380 \mathrm{C}$, que é comumente adotada em tratamento de calor. MARTELLI (1986) também afirma que o vírus é eliminado com certa dificuldade através da termoterapia. 
Os resultados de termoterapia obtidos por RIVES (1972), de que o vírus do mosaico amarelo e o vírus do mosaico das nervuras são diferentes, foram confirmados por BoveY (1972a) que não encontrou relação serológica entre os 2 agen tes.

0 vírus do mosaico das nervuras é facilmente transmitido por união de tecidos. O agente causal ainda não foi transmitido mecanicamente ou seja, através de friç̧ão de suco de videiras infetadas em plantas-teste herbáceas e em videiras (VUITTENEZ, 1970; HEWITT et aIi i, 1972; BOVEY, 1972a e VERDEREVSKAJA et alii, 1983). Tentativas de transmissão através de encostia de videira infetada em plantas-teste como Chenopodium quinoa, C. amaranticolor, Gomphrena globusa e Vinca rosea bem como testes de recuperação a partir dessas plantas deram resultados negativos (HEWITT et alii, 1972). Resultados de observaçóes e de testes de indexação demonstra ram também que o vírus do mosaico das nervuras não se transmite através de semente (DOAZAN \& BELLEGARDE, 1977; DOAZAN, 1978 e HEVIN et alii, 1973b). Não foram notados casos de in fecção de plantas sadias por pölen de plantas infetadas (DOA ZAN \& BELLEGARDE, 1977 e DOAZAN, 1978). Em outro tipo de ex perimento, WOODHAM \& KRAKE (1983) conseguiram infetar plantas sadias da variedade indicadora Rupestris du Lot através de união por meio de cuscuta (Cuscuta campestris) com plantas com mosaico das nervuras. Não conseguiram, contudo, infetar plantas herbaceas como C. quinoa, G. globosa, Nicotia na spp., cowpea, feijoeiro, etc,, por meio de 1 igações com cuscuta ou inoculação mecānica com tecidos de cuscuta que ha via se estabelecido em videira infetada. A disseminação do vïrus do mosaico das nervuras sob condições naturais não é conhecida. HEWITT (1968), em uma tentativa de grupar as vi roses existentes na época, inclui o vírus dentro do grupo dos que não têm vetores conhecidos, mas provavelmente transmitidos por insetos. VUITTENEZ (1978) afirma que, como o 
mosaico das nervuras ë de identificação mais recente, não existe ainda evidência definida sobre uma possível dissemina ção natural através de vetor. Assim sendo, a ocorrência do vírus nos vinhedos é atribuỉda à perpetuação através da propagação vegetativa de material infetado de copa e de cavalo (BOUBALS, 1971; GOHEEN, 1977; UYEMOTO et alii, 1978; BOVEY et ali, 1980 e MARTELLI, 1986).

Embora muito pouco se conheça sobre a origem do vírus do mosaico das nervuras, HEWITT (1978) o inclui como um dos vírus que teriam aparecido no centro de origem de V. vinifera ou seja, nas proximidades do mar cáspio e na Esia Menor. As videiras européias têm tolerância ao vírus (uma forma de resistência), sendo comumente aceito que as formas resistentes geralmente aparecem nos centros de origem das espécies.

- mosaico das nervuras pode ser facilmente con trolado através do emprego de material propagativo sadio de variedades de copa e de porta-enxerto, visto que não hä evidência sobre a existência de um vetor do vírus (VALAT, 1972; DETH, 1973; BOVEY et alii, 1974 e 1975, MARTELLI et alii, 1978, UYEMOTO et alii, 1978; GOHEEN, 1980 e YAMAGUCH, 1983).

A obtenção de clones sadios tem sido feita por meio da indexação de plantas empregando videiras indicadoras e da adoção de medidas curativas, como a termoterapia e cultura de tecidos. A técnica da termoterapia mais utilizada é aquela que se baseia na manutenção de plantas infetadas para vegetação dentro de câmara a $36-380 \mathrm{C}$ durante períod.o mínimo de 60 dias para posterior propagação dos ápices de 10 a $50 \mathrm{~mm}$ de comprimento dos brotos emitidos (GOHEEN) a 1 i , 1965; BOVEY, 1972b; BOVEY et a 1ii, 1974; RIVES, 1972; OTTENWAELTER et a1ii, 1973; MARTELLI et a1ii, 1978 e KUNIYUKI \& BETTI, 1987). Outra técnica de tratamento por calor 
adotada com sucesso na eliminação do vírus do mosaıco das ner vuras baseia-se na enxertia de gemas dormentes infetadas em por ta-enxertos sadios e manutenção dessas combinações em câmara a $380 \mathrm{C}$ durante $60 \mathrm{dias}$ no mínimo (GOHEEN \& LUHN, 1973 e MARTELLI et ali , 1978).

Combinaçóes da termoterapia com cultivo in vitro também vêm sendo experimentadas, com oblenção de resultados positivos na eliminação do vírus do mosaico das ne r vuras. Sáo os casos do cultivo de ápices caulinares em meio nutritivo submetidos a 2 ou 3 tratamentos iguais e sucessivos a $350 \mathrm{C}$ durante 3 meses (VALAT et alii, 1979), da microenxer tia de meristema $(0,1$ a $0,3 \mathrm{~mm})$ de videiras submetidas a $370 \mathrm{C}$ durante 1 mês e meio em entre-nós enraizados e cultivados in vitro (AYUSO \& PE NA-INGLESIAS, 1978) e da enxertia de ápices caulinares de 1 a 2 mm de plantas submetidas a $380 \mathrm{C}$ durante 60 a 600 dias em plantinhas de semente crescendo em meio de cultura (BASS et alii, 1978). Além disso, BARLASS et alii (1982) conseguiram regenerar plantas livres do mosa co das nervuras quando cultivaram tecidos contendo meristema de cerca de $1 \mathrm{~mm}$ de comprimento em meio líquido e a seguir, subdivididos e colocados em meio de cultura sólido para desenvolvimento e enraizamento.

A seleção ou uso de material de videira resis tente ao vírus do mosaico das nervuras não são empregados nos principais centros vitícolas do mundo. para esse vírus, não há necessidade de se aplicar essa medida de controle, pois não existem evidências de disseminação natural e consequlente mente, a utilização de material propagativo sadio promove o controle da moléstia. 


\section{MATERIAL E MÉTODOS}

Os experimentos foram em sua maioria conduzí dos sob condiçóes de casa de vegetação e ao ar livre na seção de Virologia do Instituto Agronómico de Campinas. Alguns testes mais específicos foram feitos nos laboratórios de patologia, microscopia electrônica e de cultura de tecidos des sa seção. observações de campo foram feitas em vinhedos de a lgumas importantes regióes vitícolas de são paulo.

o material propagativo utilizado nos experimen tos pertenceu às diferentes variedades e híbridos de vide ra, tanto de copa como de porta-enxerto. Esse material foi coletado de plantas mantidas na seção de viticultura e nas estações experimentais de Jundiaí e de são Roque do Instituto Agronômico; e de plantas cultivadas nas principais äreas produtoras do Estado como Atibaia, Itupeva, Jundiaí, Louveira, Mogi das Cruzes, São Miguel Arcanjo, São Roque, etc. A coleta foi feita de ramos lenhosos e dormentes de julho a agosto, quando as plantas encontravam-se em repouso de inver no. Uma parte dos ramos coletados de cada videira foi dividida em estacas de 2 a 3 gemas $(300$ a $400 \mathrm{~mm})$ e colocadas em vasos para enraizamento, brotação e posterior utilização da planta obtida. A outra parte foi guardada em geladeira a aproximadamente $50 \mathrm{C}$, sendo os ramos retirados apenas para as enxertias das gemas durante a época de crescimento vegetati vo. 
As observações para estudo da sintomatologia foram feitas em campo 2 a 3 vezes dentro do periodo que vai desde a brotação de primavera (setembro) até o início da maturação dos frutos (dezembro), uma vez que em videiras sens veis os sintomas são perceptíveis 1 a 2 meses após o in icio do desenvolvimento vegetativo. Exames de sintomas foram tam bëm feitos de abril a junho, nas novas brotaçöes da copa e nas brotações espontāne as dos porta-enxertos. As observaçöes foram efetuadas durante 2 a 3 anos consecutivos.

Para os testes de determinação da incidência do vírus do mosaico das nervuras por união de tecidos, os ra mos foram coletados separadamente por planta e de plantas ao acaso durante a fase de repouso de inverno. Nesse período, não era possível reconhecer os sintomas da moléstia nas variedades que os exibem em época apropriada.

A identificação du mosaico das nervuras foi baseada nas reaçóes apresentadas pela videira indicadora $\mathrm{Ru}-$ pestris du Lot (St. George), que é rotineiramente adotada pa ra deteç̧ão do vírus em outros países (HEWITT et alii, 1972 e BOVEY et alii, 1980), e também pelos porta-enxertos kober 5 B.B e Golia.

Os materiais sadios foram representados por clones de variedades comerciais e não comerciais de copa e de porta-enxerto, considerados livres do vírus do mosaico das nervuras através de testes de indexação empregando videiras indicadoras ou então, através da termoterapia.

As fontes de vîrus us adas para o desenvolvimen to dos estudos foram representadas por plantas da indicadora Rupestris du Lot infetadas por isolados comuns, dada a facilidade de manuseio pelo fato de mostrarem sintomas. Plan tas de uva Itália também foram empregadas como fornecedoras 
de inóculo, pelos fatos de estarem infetadas com alta incidência pelo vírus e de serem facilmente encontradas em campo para obtenção de material propagativo. Outros isolados do virus de interesse aos experimentos foram mantidos nas plantas nas quais foram detectados, independente de varieda de. Esse mesmo procedimento foi adotado para as diferentes combinações do vírus do mosaico das nervuras com outros vírus da videira assinalados em São paulo, sejampara as encon tradas naturalmente em condiçóes de campo (cascudo, enrolamen to da folha e fendilhamento cortical), sejam para as feitas artificialmente, representadas por combinaçóes das quais fez parte o vírus do mosaico do Traviú.

As plantas de videira utilizadas em alguns experimentos foran obtidas de sementes coletadas em janeiro e fevereiro, época da maturação dos frutos sob condições nor mais de cultivo da videira em Säo Paulo., Essas sementes foram submetidas a um tratamento preliminar, mantendo-as durante 1 mês ou mais, estratificadas em areia umedecida em caixas de petri a temperatura em torno de $50 \mathrm{C}$ num refrigera dor (SANTOS NETO, 1955). Após completado o período de trata mento, a semeadura foi feita em recipientes de plástico ou de barro, de $320 \times 320 \times 80 \mathrm{~mm}$ ou $250 \times 250 \times 80 \mathrm{~mm}$, cheios de mistura de terra mais esterco de curral, näo esterilizado. De modo geral, o tratamento baseado no choque de frio foi feito de junho a julho e a semeadura em agosto e setembro, pois nes sa época, a temperatura e a luminosidade são mais favoráveis para boa germinação das sementes e räpido crescimento das plantas. Quando estas atingiram 30 a $50 \mathrm{~mm}$ de altura, foram transplantadas individualmente ou em grupos de 2 a 3 para vasos, dependendo da finalidade dos experimentos.

As plantas herbáceas empregadas nos testes de inoculação mecânica foram representadas por numerosas espécies comumente adotadas nos estudos com vírus. Essas plan- 
tas foram conseguidas do setor de produção de plantas testes da Seção de Virologia do Instituto Agronômico.

A maioria das plantas utilizadas nos estudos foi manuseada e mantida em vasos de aluminio de $150 \mathrm{~mm}$ de diâmetro e $160 \mathrm{~mm}$ de altura. Mas a quase totalidade das plan tas inoculadas das videiras indicadoras foi transferida para recipientes maiores, normalmente sacos plásticos de $280 \mathrm{~mm}$ de diâmetro e $350 \mathrm{~mm}$ de altura. Videiras sadias e infetadas destinadas à propagação foram mantidas em sacos plásticos de 400 a $500 \mathrm{~mm}$ de diámetro e 500 a $600 \mathrm{~mm}$ de a $1 \mathrm{tura}$, ou então, plantadas diretamente no solo.

Os testes baseados na enxertia foram executa dos mediante adoção de diferentes técnicas, mas as mais empregadas foram:

a) enxertia de brotos de 50 a $100 \mathrm{~mm}$, de cres cimento vigoroso, por garfagem em ramos herbáceos de plantas de estaca, para que nestas fosse observado o aparecimento de sintomas. o pegamento da enxertia foi observado depois de 15 a 30 dias (Figura 1 , A);

b) enxertia de gema em planta de estaca, para que nesta fosse observado o aparecimento de sintomas. Essa técnica foi adotada tanto com material em estado herbáceo co mo lenhoso, sendo o pegamento da enxertia confirmado depois de 15 a 30 dias para o primeiro caso e de 2 a 3 meses para o segundo caso (Figura $1, B$ e C);

c) enxertia de gema indicador a em ramos de planta infetada ou a ser testada para efetuar a leitura de sintomas em sua brotação. De modo geral, o pegamento pode ser avaliado aos 15 a 30 dias da enxertia, quando o material era herbáceo e aos 35 a 50 dias, quando o material era lenhoso (Figura 1, D). 


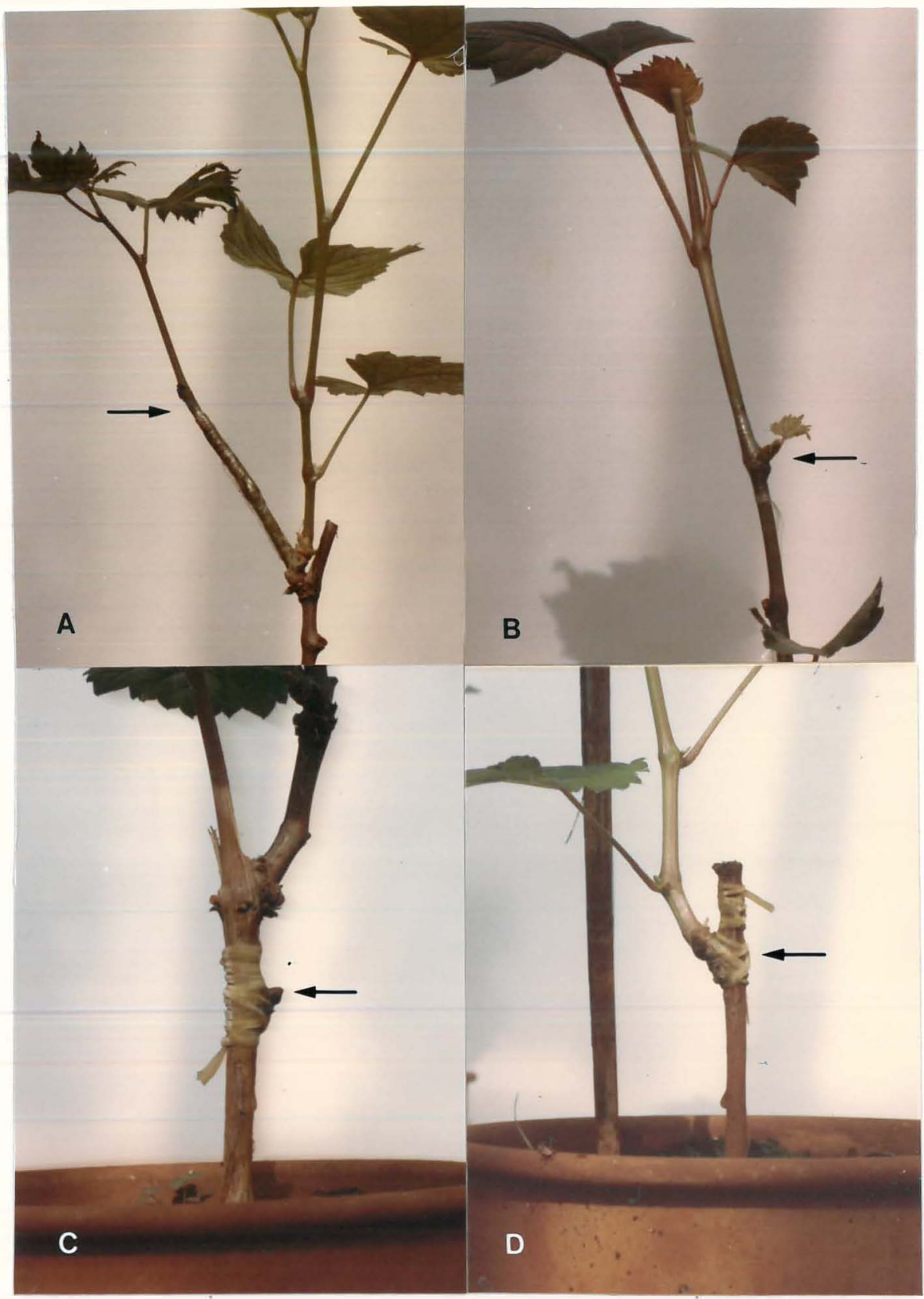

Figura 1. Métodos de união de tecidos empregados para a trans missão do vírus do mosaico das nervuras da videi= ra. A - Enxertia de broto por garfagem. B - Enxertia de gema de ramo herbáceo. C - Enxertia de gema de ramo dormente. D - Enxertia de gema indicadora de ramo dormente. 
Nas técnicas mencionadas em (a) e (b), os bro tos e as gemas foram provenientes de plantas infetadas ou a serem testadas; as plantas de estaca foram de variedades indicadoras ou então, de variedades cuja susceptibilidade se procurou verificar.

As enxertias foram feitas dentro do período de agosto a fevereiro, portanto em época em que as videiras estão em pleno desenvolvimento vegetativo sob condiçóes de casa de vegetaçáo. No caso da enxertia de brotos, foi adotada a garfagem do tipo fenda completa, segundo a qual a parte inferior do garfo é cortada na forma de cunha e a seguir, introduzida na fenda perpendicular $(10$ a $20 \mathrm{~mm})$ feita no ramo podado da planta receptora. Nos casos em que se procedeu a enxertia de gema, independente dos métodos, fez-se um corte ligeiramente oblíquo no ramo da planta receptora $(10$ a $20 \mathrm{~mm}$ de comprimento) e a seguir, outro corte com àngulo de 450 em relação a o primeiro ( 3 a $5 \mathrm{~mm}$ de profundidade) até atingir a extremidade inferior deste. Em seguida, retirou-se o pedaço resultante e encaixou-se um outro, de igual tamanho e maturação, contendo uma gema. Essa técnica, quando aplicada em material lenhoso, é denominada "cíip budding" na língua inglesa. Nas enxertias em que se adotou tecidos herbáceos, as partes foram mantidas unidas até o pegamento com fitas de plástico. No caso la enxertia de gema de ramo lenhoso, a amarração foi feit a com elástico e a seguir, coberta totalmente com cera de abelha derretida. Na enxertia de gema indicadora, é indispensável o decepamento da planta logo acima do ponto de união dos tecidos, para favorecer a brotação daque 1 a.

0 reconhecimento de sintomas do mosaico das nervuras nas videiras indicadoras baseou-se na observaçáo de fol has jovens e médias dos ramos resultantes da brotação de primavera originadas depois do inverno seguinte ao ciclo em 
que foi feita a enxertia ( 8 a 15 meses); nos casos negativos, essa leitura foi repetida nas folhas da brotação formada de pois do segundo inverno ( 20 a 27 meses). Nos testes de sele ção de material propagativo sadio, considerou-se um clone como livre do virus do mosaico das nervuras quando os resultados nas indicadoras foram negativos durante 3 ciclos vegetativos ver dadeiros.

Nos experimentos em que se procurou induzir o aparecimento de sintomas do mosaico das nervuras nas brotaçöes fora de época, videiras indicadoras infetadas em cres cimento vigoroso foram colocadas para desenvolvimento ao ar livre, tanto ao sol como á sombra, sob condiçóes de laborató rio e dentro de cámara de temperatura amena. Neste caso, o tratamento consistiu na colocação de videiras, durante alguns dias, dentro de câmara de temperatura a $200 \mathrm{C}$ e sob 10 horas de iluminação diária, fornecida por 2 lâmpadas fluores centes de 40 , do tipo $1 \mathrm{uz}$ do dia, situadas no teto, a cerca de 3 metros das plantas (GUIRADo et ali , 1986).

As tentativas de transmissão do vírus do mosaico das nervuras por inoculação mecānica foram feitas mediante maceração de tecidos novos de videira infetada (folhas, raízes, calos, etc.) em presença de nicotina a $2,5 \%$ em àgua e posterior fricção do suco obtido na superfície das folhas das videiras e das plantas-teste herbáceas previamen te polvilhadas com carborundo. Essa técnica é a mais adotada para os vírus mecanicamente transmissiveis da videira (CAD MAN et alii, 1960; DIAS, 1965).. Outros diluentes, tais como à base de cafeína, sulfito de sódio, dietilditiocarbamato de sódio, tampão fosfato e borato, etc., também foram empregados, porém em menor escala. o pH dos diluentes variou de 7,0 a 10,0. As plantas herbáceas inoculadas foram mantidas sob observação durante 30 a 40 dias e as videiras, durante 15 a 20 meses. 
Quatro outros métodos de inoculação mecānica for am também adotados, mas em menor escala. o primeiro, cha mado de pica-couve, consistiu em enrolar folha de videira com mosaico das nervuras, cortar e logo em seguida, esfregar na superfície das folhas das plantas-teste, inclusive videira. o segundo foi a pseudo-encostia, que consistiu em promover a união física dos ramos herbáceos de videira infetada com os das espécies herbáceas. O terceiro baseou-se em cortar pequenos pedaços de pecíolos, ramos novos ou casca de ramos herbáceos de videira infetada dentro de uma solução de tam páo fosfato pH 7,0 ou 8,0 , adicionado ou não de sulfito de sódio, coar em papel de filtro e 10 go em seguida, efetuar 50 a 60 cortes na casca dos ramos verdes e lenhosos de videiras sadias com a lámina do canivete de enxertia molhada no suco obtido. 0 ültimo método consistiu em depositar gotas do suco conseguido de acordo com o método adotado no terceiro caso, na superfície cortada de um ramo de videira sadia, logo acima do ponto de inserção de um broto em crescimento vigoro so.

As tentativas de observação de partículas virais associadas ao mosaico das nervuras em tecidos de videira infetada foram feitas no Setor de Microscopia Electrónica da seçáo de Virologia do Instituto Agronómico, pela técni ca de imersáo foliar rápida e de seçõos ultrafinas.

A obtenção de material propagativo sadio foi feita empregando 2 métodos: (a) seleção através de testes de indexaçáo de plantas de campo utilizando videiras indicadoras, principalmente o Rupestris du Lot e (b) adoção de medidas curativas, como a termoterapia e microenxertia.

Com relação à termoterapia, 2 técnicas foram adotadas: (a) tratamento de estacas dormentes a $380^{\circ} \mathrm{Cem}$ es tufa de ar quente (FANEM, mode $10061 / 4$ ), sob condiçoes escu- 
ras, até apresentar sinal de perda de viabilidade. Após o tratamento, as gemas dessas estacas foram enxertadas em porta-enxertos sadios, para obtenção de plantas. A fim de impe dir perda de umidade, as estacas com 1 gema ou com 2 ou mais foram cobertas totalmente ou apenas nas extremidades com cera de abelha derretida, embrulhadas em papel alumínio e acon dicionadas em sacos plásticos com suas aberturas fechadas com fita adesiva (YUKI et alii, 1973) e (b) tratamento baseado na manutenção das plantas infetadas para ve getação dentro de câmara de temperatura controlada a $36-380 \mathrm{C}$ e sob $12-16$ ho ras de iluminação díária durante período mínimo de 60 dias. Em seguida, ápices caulinares de cerca de $10 \mathrm{~mm}$ de comprimento dos brotos apicais e axilares emitidos durante o trata mento foramenxertados em plantas de semente ou de estaca sadias (KUNIYUKI \& BETTI, 1987). Propagações foram também feitas mediante enraizamento em meio de cultura de ápices de 2 a $3 \mathrm{~mm}$ dos brotos emitidos (KUNIYUKI et a $1 \mathrm{i}$, 1987).

A microenxertia consistiu na tentativa de enxertia de aṕices caulinares, medindo cerca de 0,5 a $0,7 \mathrm{~mm}$ e com 2 a 3 primórdios foliares, retirados de brotos vigorosos de plantas infetadas, não submetidas a tratamento de calor. As enxertias foram feitas segundo 2 técnicas: (a) deposição dos ápices contendo meristema no corte feito na cas ca dos ramos jovens e suculentos de plantas de estaca sadias e mantidas sob condiçóes de cas a de vegetação e (b) coloca f̧ão do segmento caulinar na região do anel vascular da super fície exposta do caule decepado de plantinhas de semente es tioladas obtidas em meio de cultura. As operaçóes para obten. ção desses ápices e deposição dos mesmos nos porta - enxertos foram feitas com auxîlio de microscópio estereoscópico.

Nos estudos que envolveram cultivo in vitro, foi adotado o meio básico de MURASHIGE \& Skoog (1962), com pH ajustado a 5,6. Para o enraizamento dos ápices de 2 a 3 
$\mathrm{mm}$ de plantas submetidas a termoterapia, foram adicionados o carvão ativado $(5,0 \mathrm{~g} / \mathrm{I})$ e 6-benzilaminopurina ( 5,0 HM). Para as tentativas de microenxertia, foram acrescentados ao meio básico, a benziladenina $(1,4 \mu \mathrm{M})$ e ácido indol butírico $(0,7 \mu \mathrm{M})$. A seguir, as partes propagativas foram mantidas em condições de laboratório, com temperatura aproximada de 25 a $270 \mathrm{C}$ e com fotoperíodo de 16 horas.

o material e métodos mais específicos serão descritos junto com a apresentação dos resultados. 


\section{RESULTADOS}

\subsection{IMPORTÂNCIA ECONÔMICA}

\subsubsection{Avali ação da incidência em $\mathrm{S}$ ão $\mathrm{Paulo}$}

Determinaçóes feitas através do emprego de ví deiras indicadoras em amostras de 44 variedades de copa e de 19 porta-enxertos demonstraram que o vírus do mosaico das nervuras encontra-se presente em vinhedos de todas as principais regióes vitícolas do Estado. Os resultados dos testes feitos para as variedades de copa encontram-se na Tabela 1. Indicam que todas as variedades testadas encontravam-se infetadas pelo vírus em maior ou menor porcentagem. Doze achavam-se $100 \%$ infetadas e 32 com incidências entre 17 e $87 \%$. Quando se contou o nümero de plantas testadas de todas as va riedades, a porcentagem de infecção atingiu 58\%. Observa-se que a uva Itália (Pirovano 65), variedade mais importante co mo produtora de uva fina do Estado, achava-se $100 \%$ infetada. Dentre as amostras testadas dessa videira, uma era representada por 4 plantas com aproximadamente 30 anos de idade na época da coleta de material propagativo, que foi feita em 1972, na propriedade do senhor Arakawa, em Ferraz de Vasconcelos, SP. A Itália Rubi, também conhecida por ltália Rosada, resultante de mutação somática da variedade ltália, também estava $100 \%$ infetada. Ainda de acordo com a Tabela 1, as 16 variedades criadas no Instituto Agronómico de Campinas (séries IAC da Seção de Viticultura, Jundiaí 242 e Jundiaí 930 
Tabela 1. Porcentagem de infecção pelo vírus do mosaico das nervuras em amostras das principais variedades de copa de videira cultiva. das ou mantidas em coleção em São Paulo.

$\begin{array}{llll}\begin{array}{l}\text { Variedades de loca } \\ \text { lidades } \\ \text { de copa }\end{array} & \text { No de plantas } & \% \text { de } \\ \text { testadas infetadas } & \text { infecção }\end{array}$

\begin{tabular}{|c|c|c|c|c|}
\hline Alphonse Laval lée & 2 & 10 & 6 & 60 \\
\hline Aramon & 1 & 1 & 1 & 100 \\
\hline Barbera & 1 & 8 & 4 & 50 \\
\hline Bonarda & 1 & 10 & 6 & 60 \\
\hline Cabernet Franc & 1 & 9 & 3 & 33 \\
\hline Concord & 1 & 13 & 4 & 30 \\
\hline IAC $116-31$ & 2 & 7 & 2 & 28 \\
\hline IAC $138-22$ & 4 & 22 & 10 & 45 \\
\hline IAC $457-11$ & 2 & 9 & 9 & 100 \\
\hline IAC $460-1$ & 1 & 6 & 6 & 100 \\
\hline IAC $514-6$ & 2 & 10 & 4 & 40 \\
\hline IAC $536-2$ & 1 & 4 & 2 & 50 \\
\hline IAC $842-4$ & 2 & 9 & 3 & 33 \\
\hline IAC $871-13$ & 3 & 20 & 4 & 20 \\
\hline IAC $871-41$ & 4 & 19 & 6 & 31 \\
\hline IAC $960-12$ & 2 & 10 & 5 & 50 \\
\hline IAC $775-26$ & 2 & 12 & 12 & 100 \\
\hline IAC $1398-21$ & 2 & 10 & 7 & 70 \\
\hline IAC $1596-16$ & 2 & 6 & 6 & 100 \\
\hline Is abe 1 & 4 & 33 & 10 & 30 \\
\hline Itālia & 13 & 108 & 108 & 100 \\
\hline Itälia Rubi & 6 & 56 & 56 & 100 \\
\hline Jacquez & 1 & 3 & 1 & 33 \\
\hline JD 242 & 1 & 8 & 3 & 37 \\
\hline JD 930 & 1 & 6 & 3 & 50 \\
\hline
\end{tabular}


Tabela 1. Porcentagem de infecção pelo vỉrus do mosaico das nervuras em amostras das principais variedades de copa de videira cultiva das ou mantidas em coleção em São Paulo (continuação)

Variedades
de copa

Nọ de loca

lidades amostradas
Nọ de plantas

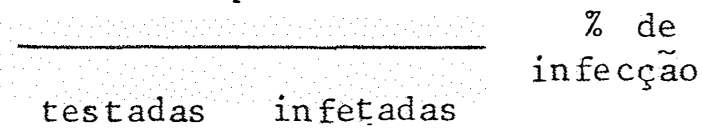

\begin{tabular}{|c|c|c|c|c|}
\hline Kioho & 4 & 36 & 36 & 100 \\
\hline Kioho Rosada & 1 & 4 & 4 & 100 \\
\hline Merlot & 2 & 10 & 3 & 30 \\
\hline Moscate 1 de Hamburgo & 2 & 10 & 7 & 70 \\
\hline Moscatel Rosado & 1 & 8 & 2 & 25 \\
\hline Niagara Branca & 9 & 135 & 62 & 46 \\
\hline Niagara Rosada & 12 & 235 & 78 & 33 \\
\hline Olimpia & 3 & 17 & 17 & 100 \\
\hline Perlona & 2 & 8 & 7 & 87 \\
\hline Pinot Noir & 1 & 10 & 4 & 40 \\
\hline Seibe 12 & 5 & 53 & 30 & 56 \\
\hline Seibe 15455 & 1 & 3 & 3 & 100 \\
\hline Seibe1 7053 & 2 & 10 & 6 & 60 \\
\hline Seiel 10096 & 1 & 8 & 6 & 75 \\
\hline sémillon & 1 & 12 & 5 & 42 \\
\hline SR 496-15 & 1 & 6 & 1 & 17 \\
\hline Sultanina & 2 & 8 & 2 & 25 \\
\hline Syrah & 1 & 10 & 3 & 30 \\
\hline Seyve Villard 5276 & 4 & 48 & 48 & 100 \\
\hline Total & & 1040 & 605 & 58 \\
\hline
\end{tabular}


da Estação Experimental de Jundiaí.e SR 496-15 da Estação Ex perimental de são Roque) apresentaram porcentagens de infecção entre 17 e $100 \%$. A incidência média do vírus nessas variedades foi de $50 \%$, quando se calculou a relação entre o nü mero de plantas testadas e infetadas. A incidencia do vírus em plantas das variedades kioho e 0limpia, originadas de material propagativo introduzido do Japão, e de kioho Rosada, mutante somático de kioho, foi de $100 \%$. Considerando apenas as variedades de maior importäncia dentro da viticultura comercial de Sáo paulo (IAC 138-22, IAC 871-13, IAC 87141, Isabel, Itália, Itália Rubi, Niagara Branca, Niagara Rosada, seibel 2 e Seyve villard 5276), a incidência média foi de $56 \%$.

Quando os dados sobre a incidência do vírus do mosaico das nervuras em 12 variedades foram grupados por região (Tabela 2), observou-se que as 7 variedades parcialmente infetadas mostraram variaçöes bastante significativas entre diferentes 10 calidades do Estado. Nesse caso, as regióes de Mairinque e São Roque foram as que apresentaram maior fre qléncia do vírus. Para as outras 5 variedades que já se achavam totalmente infetadas, obviamente, o indice de infecção foi o mesmo para todas as regióes consideradas.

Com relação às plantas matrizes dos porta-enxertos, os resultados encontram-se na Tabe 1 a 3 . Dos 19 porta-enxertos testados, 7 apresentaram-se livres do vírus e 12 com porcentagens de infeção entre 12 e $75 \%$. Quando se considerou o nümero total de plantas testadas dos 19 porta-enxertos, a incidência do vírus foi de $18 \%$. Os porta-enxertos tradicionais mais empregados em São paulo (Kober 5BB, Rupestris du Lot, Traviú e 420A) mostraram porcentagem de infecfáo entre 12 e $24 \%$. Os obtidos no Instituto Agronómico de Campinas (IAC 313, IAC 571-6, IAC 572, IAC 766 e SR 26) deram resultados negativos nos testes feitos. 


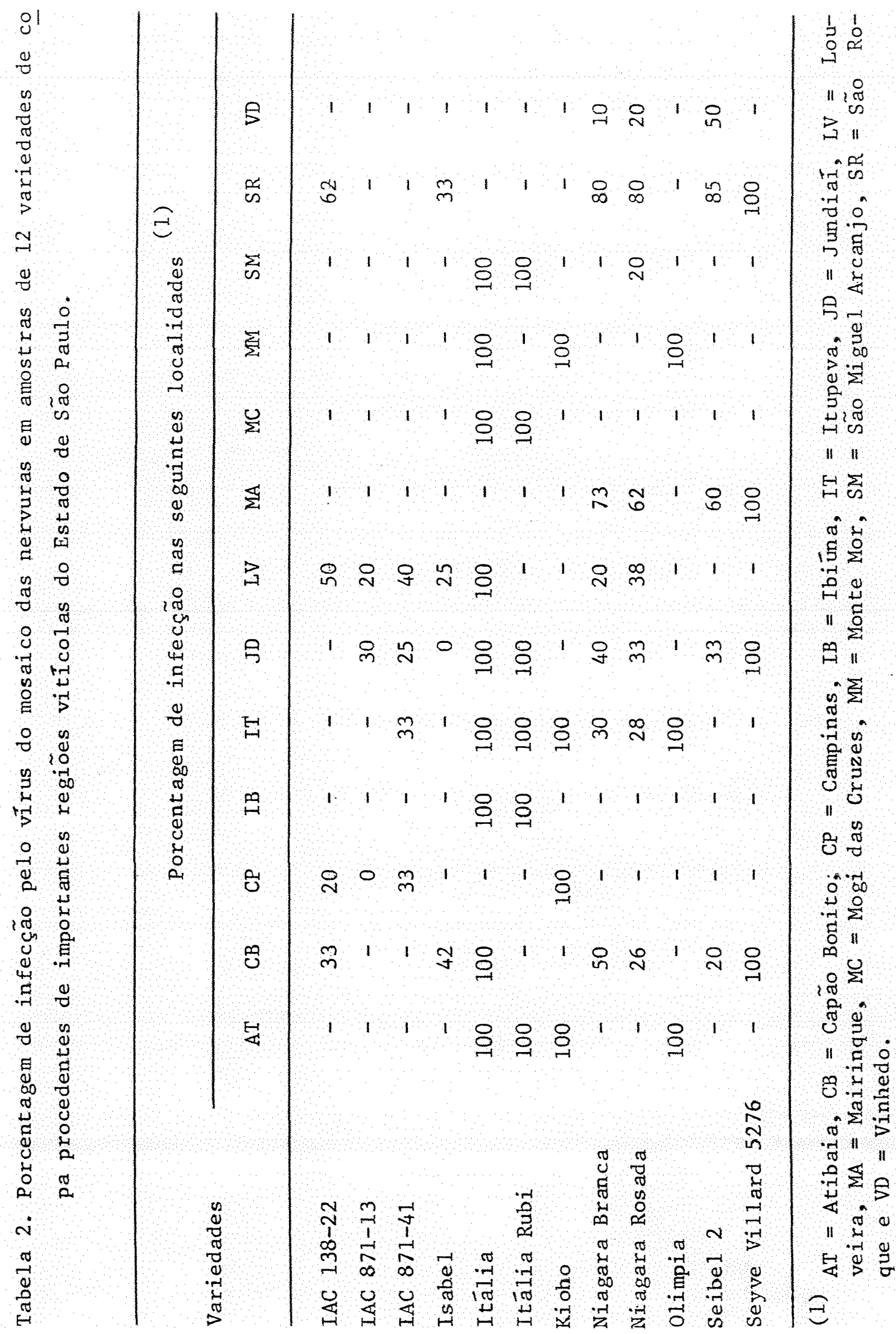


Tabela 3. Porcentagem de infecção pelo vírus do mosaico das nervuras em amostras de plantas matrizes dos principais porta-enxertos de videira utilizados ou mantidos em coleção em São Paulo.

\begin{tabular}{|c|c|c|c|c|}
\hline \multirow{2}{*}{ Porta-enxertos } & \multirow{2}{*}{$\begin{array}{l}\text { No de 1o- } \\
\text { lidades } \\
\text { amostradas }\end{array}$} & \multicolumn{2}{|c|}{ NO de plantas } & \multirow{2}{*}{$\begin{array}{c}\% \text { de } \\
\text { infecção }\end{array}$} \\
\hline & & testadas & infetadas & \\
\hline Couderc & 1 & 2 & 1 & 50 \\
\hline Golia & 3 & 15 & 2 & 13 \\
\hline IAC 313 & 2 & 15 & 0 & 0 \\
\hline IAC $571-6$ & 1 & 10 & 0 & 0 \\
\hline IAC 572 & 1 & 6 & 0 & 0 \\
\hline IAC 766 & 2 & 12 & 0 & 0 \\
\hline Kober $5 \mathrm{BB}$ & 3 & 24 & 3 & 12 \\
\hline Riparia Portalis & 1 & 2 & 1 & 50 \\
\hline Rupestris du Lot & 4 & 42 & 10 & 24 \\
\hline $\mathrm{SO} 4$ & 1 & 5 & 1 & 20 \\
\hline SR 26 & 1 & 3 & 0 & 0 \\
\hline V. champini & 1 & 3 & 0 & 0 \\
\hline $5 \mathrm{C}$ & 1 & 3 & 1 & 33 \\
\hline $8 B$ & 1 & 4 & 3 & 75 \\
\hline $99 \mathrm{R}$ & 1 & 5 & 0 & 0 \\
\hline $110 \mathrm{R}$ & 1 & 5 & 1 & 20 \\
\hline $420 \mathrm{~A}$ & 2 & 13 & 4 & 30 \\
\hline $101-14$ & 2 & 8 & 6 & 75 \\
\hline $106-8$ & 2 & 21 & 3 & 14 \\
\hline Total & & 198 & 36 & 18 \\
\hline
\end{tabular}


ocasionalmente, foi obtido um pequeno número de amostras de material propagativo de 5 porta-enxertos mais comumente empregados no Estado e testado para o vírus do mosaico das nervuras. Essa obtenção foi feita mediante coleta de ramos dos cavalos plantados pelos viticultores para ampliação do vinhedo, não se conhecendo portanto as procedências de cada material. Na Tabela 4 estão os resultados conseguidos, segundo os quais a incidência variou de 30 a $83 \%$. A incidencia mais alta foi verificada para o IAC 313.

\subsubsection{Incidência em amostras procedentes de outros estados do Brasil}

Ao longo dos anos, a Seção de Virologia do Instituto Agronómico de Campinas tem recebido, de maneira eventual, material propagativo de videiras cultivadas em outros estados brasileiros, para ser submetido a testes de indexação empregando videiras indicadoras dos diferentes vírus dessa planta. os resultados obtidos para o vírus do mosaico das nervuras estão apresentados na Tabela 5. Mostram que a grande maioria das variedades testadas já estavam infetadas pelo yírus, em porcentagens semelhantes às de são Paulo. As plantas das variedades Cabernet Sauvignon, Merlot e Ruby Cabernet, que deram resultados negativos nos testes de deteç̧ão do vírus, resultaram de material propagat yo introduzido como livres do vírus mais comuns que ocorrem nos países tradicionalmente vitícolas.

\subsubsection{Avaliação das perdas}

As perdas quantitativas e qualitativas causadas pelo vírus do mosaico das nervuras não foram ainda deter minadas experimentalmente em são paulo, pois até há poucos 





Tabela 5. Incidência do vírus do mosaico das nervuras em material propagativo de videira procedente de outros estados do Brasil.

\begin{tabular}{|c|c|c|c|c|c|}
\hline \multirow{2}{*}{ Estado } & \multirow{2}{*}{ Origem $^{(1)}$} & \multirow{2}{*}{ Variedade } & \multicolumn{2}{|c|}{ Nọ plantas } & \multirow{2}{*}{$\begin{array}{c}\% \text { de } \\
\text { infec } \\
\text { ção }\end{array}$} \\
\hline & & & Test. & Inf. & \\
\hline \multirow[t]{2}{*}{ Goiás } & EMGOPA & Itália & 5 & 5 & 100 \\
\hline & EMGOPA & Patricia & 4 & 1 & 25 \\
\hline \multirow[t]{4}{*}{ Minas Gerais } & viticultor & Jacquez & 5 & 5 & 100 \\
\hline & viticultor & Folha de Figo & 10 & 6 & 60 \\
\hline & viticultor & Is abe 1 & 8 & 4 & 50 \\
\hline & viticultor & IAC $871-13$ & 5 & 1 & 20 \\
\hline \multirow[t]{4}{*}{ Paraná } & viticultor & Itália & 10 & 10 & 100 \\
\hline & viticultor & Itālia Rubi & 15 & 15 & 100 \\
\hline & viticultor & Kioho & 9 & 9 & 100 \\
\hline & viticultor & Kioho Rosada & 3 & 3 & 100 \\
\hline \multirow[t]{8}{*}{ Rio Grande do Sul } & viticultor & Bordeaux & 6 & 2 & 33 \\
\hline & viticultor & Is abeI & 4 & 2 & 50 \\
\hline & viticultor & Itália & 3 & 3 & 100 \\
\hline & E.E.Cx.Su1 & Perlona & 6 & 6 & 100 \\
\hline & E.E.Cx.Sul & Sémillon. & 12 & 5 & 42 \\
\hline & E.E.Cx.Sul & Ruby Cabernet & 1 & 0 & 0 \\
\hline & EMBRAPA & Cabernet Sauvignon & 1 & 0 & 0 \\
\hline & EMBRAPA & Merlot & 1 & 0 & 0 \\
\hline \multirow[t]{4}{*}{ Santa Catarina } & viticultor & Alphonse Laval lée & 5 & 5 & 100 \\
\hline & viticultor & Golden Queen & 3 & 2 & 66 \\
\hline & viticultor & Itālia & 5 & 5 & 100 \\
\hline & viticultor & Perlona & 3 & 3 & 100 \\
\hline
\end{tabular}

(1) EMGOPA = Empresa Goiana de Pesquisa Agropecuária, E.E. Cx.sul = Esta f̧ão Experimental de Caxias do Sul, RS e EMBRAPA = Empresa Brasilei= ra de Pesquisa Agropecuäria, Bento Gonçalves, RS. 
anos, não se dispunha de clones comprovadamente isentos de virus das principais variedades para a realização de ensaios comparativos.

observaçøes feitas permitiram notar que plantas sadias das variedades Itälia, Itälia Rubi, Kioho e seyve Villard 5276, obtidas através da termoterapia, eram bem mais vigorosas do que as do mesmo clone infetadas pelo vírus. As plantas sadias dos porta-enxertos kober 5 BB e Rupestris du Lot, obtidas através de testes de indexação, também apresentaram maior desenvolvimento vegetativo em relação às infetadas.

\subsection{CIRCULO DE HOSPEDEIRAS}

Experimentos de transmissão foram executados no sentido de determinar o círculo de hospedeiras do vírus do mosaico das nervuras que ocorre comumente em sáo paulo e também, de verificar as reações apresentadas à infeç̧ão por essas plantas.

os resultados dos testes de transmissão por uniăo de tecidos, em que foram inoculadas 3 a 5 plantas sadias do mesmo clone de diferentes variedades, híbridos es pécies de Vitis, encontram-se na Tabela 6. Mostram que todas as videiras foram susceptíveis ao vírus do mosaico das nervuras, uma ve $z$ que este foi recuperado para a indicadora Rupestris du Lot de todas as videiras testadas. Apenas 3 porta-enxertos exibiramsintomas, todos do tipo palidez das nervuras menores, sendo eles o Golia, Kober 5 BB e Rupestris du Lot. Não foram notadas alterações na intensidade de sintomas em Rupestris du Lot nos testes de recuperação e nem en contrada alguma dificuldade na recuperação desse vírus de al gumas das videiras inoculadas. 
Tabela 6. Reação apresentada por plantas de diferentes variedades e híbridos de Vitis inoculados com o virus do mosaico das nervu ras e recuperação para videira indicadora Rupestris du Lot.

\begin{tabular}{|c|c|c|}
\hline $\begin{array}{l}\text { Videiras } \\
\text { testadas }\end{array}$ & $\begin{array}{l}\text { Reação positiva } \\
(+) \text { ou negativa } \\
(-) \text { apresentada } \\
\text { pelas videiras } \\
\text { testadas }\end{array}$ & $\begin{array}{l}\text { Recuperação } \\
\text { positiva(t) } \\
\text { do virus em } \\
\text { videiras in } \\
\text { dicadoras }\end{array}$ \\
\hline V. bourquina: Jacquez & - & + \\
\hline V. caribaea (De Candolle) & - & + \\
\hline V. champine planchon & - & + \\
\hline V. gigas Fenne1 & - & + \\
\hline V. labrusca L.: Concord & - & + \\
\hline V. riparia Michaux: Riparia Gloire & - & + \\
\hline V. rupestris scheele, du Lot & + & + \\
\hline \multirow{4}{*}{ V. vinifera L. . Cabernet Franc } & - & + \\
\hline & - & + \\
\hline & - & + \\
\hline & - & + \\
\hline \multirow{3}{*}{$\begin{array}{l}\text { V. labrusca } \times \text { V. vinifera: Isabe } 1 \\
\text { Niagara } \\
\text { U. berlandieri } \mathrm{P} 1 \text { anchon } \mathrm{x} \text { V. riparia. }\end{array}$} & - & + \\
\hline & - & + \\
\hline & & \\
\hline $420 \mathrm{~A}$ & - & + \\
\hline Kober $5 \mathrm{BB}$ & + & + \\
\hline V. riparia $\times$ V. rupestris: $101-14$ & - & + \\
\hline V. smalliara x Golia: IAC 313 & - & + \\
\hline $\begin{array}{l}\text { V. riparia } \times \text { V. rupestris } \times \text { V. cordifol } \\
\text { Michaux: } 106-8 \text { (Travi } \bar{u} \text { ) }\end{array}$ & $i a$ & + \\
\hline $\begin{array}{l}\text { V. riparia } \times \text { V. vinifera } \times \text { V. rupestris } \\
\text { Golia }\end{array}$ & + & + \\
\hline $\begin{array}{l}\text { V. vinifera } \times \text { V., rupestris } \times \text { } V \text {, lincece } \\
\text { Buckley: Seibel } 2\end{array}$ & mil & + \\
\hline $\begin{array}{l}\text { V. vinifera } \times \text { V. labrusca } \times \text { V. riparia } \\
\text { V. candicans Engelmann: LN-33 }\end{array}$ & - & + \\
\hline
\end{tabular}


Tentativas feitas para transmitir o vírus do mosaico das nervuras através de inoculação mecânica em diver sas plantas herbáceas deram resultados negativos, conforme descritos adiante.

\subsection{Sintomatologia}

De modo geral, os sintomas do mosaico das ne vuras não são facilmente reconhecíveis nas principais variedades de copa e de porta-enxerto cultivadas em São paulo. são poucas as videiras que exibem sintomas perceptíleis. Por is so, procurou-se estudar me lhor as reaçós apresentadas pelas videiras de maior importáncia para a viticultura paulista à infecçáo pelo vírus. Aproveitou-se também a oportunidade pa ra reconhecer as anomalias de outras causas que apresentam sintomas semelhantes aos do mosaico das nervuras e que podem conduzir a erros na diagnose da virose.

\subsubsection{Sintomas do mosaico das nervuras em variedades de copa}

A grande maioria das variedades de copa examinadas, sejam de importância económica para o Estado de são Paulo ou apenas mantidas em coleção, não mostram sintomas do mosaico das nervuras. Esses foram observados em al gumas pou cas videiras. A variedade Seyve Villard 5276 apresenta fo1has jovens cloróticas, as quais, sob condif̧óes de luminosidade mais baixa, mostram palidez de algumas nervuras menores; essas manchas cloróticas podem também atingir trechos das nervuras secundárias. Nas variedades kioho e olimpia, introduzidas do Japão, as plantas exibem folhas da brotação de primavera com manchas cloróticas de pequenos comprimentos e ligeira assimetria do $1 \mathrm{imbo;}$ a $1 \mathrm{gumas}$ mostram amarelecimen 
to do limbo adjacente às nervuras principais ou secundárias (Figura 2, A e B). Além disso, apresentam desenvolvimento anormal dos ramos e maturação desuniforme dos frutos.

Algumas plantas de campo de variedades de copa como Itália, Niagara Branca, Niagara Rosada, Perlona, Pinot Noir, etc., quando indexadas, deram resultados positivos para o vírus do mosaico das nervuras e também para os vírus do enrolamento da folha, fendilhamento cortical e cascudo, revelando ocorrência de infeç̧ão simultânea. Não foi possível verificar casos de mudança nas reações das videiras as sim infetadas. Contudo, em plantas de Itália, Niagaras e Perlona, que se achavam infetadas por 3 ou 4 vírus ao mesmo tempo, verificou-se uma redução bastante evidente no desenvolvimento vegetativo.

Com o propósito de avaliar possiveis interaçôes entre os vírus registrados em são Paulo, plantas da variedade Itália e dos porta-enxertos LN-33 e Rupestris du Lot, que normalmente são adotados como indicadoras desses agentes, foram submetidas a inoculaçóes com o vírus do mosaico das nervuras em diferentes combinações com os outros presen tes nos vinhedos paulistas. Os resultados conseguidos depois de 3 a 5 anos de observações encontram-se na Tabela 7 . Não houve ocorrência de sinergismo ou al gum outro tipo de in teração que resultasse na mudança das reações de cada videira à infecção por cada vírus. As plantas, quando reagiramà infecção por determinados vírus, o fizeram com sintomas definidos para cada um destes. Além disso, foi verificado que as videiras Itália e LN-33, quando infetadas por 3 ou mais vírus, principalmente quando da mistura fez parte o vírus do fendilhamento cortical, apresentaram maior redução no vigor das plantas do que quando infetadas isoladamente. 


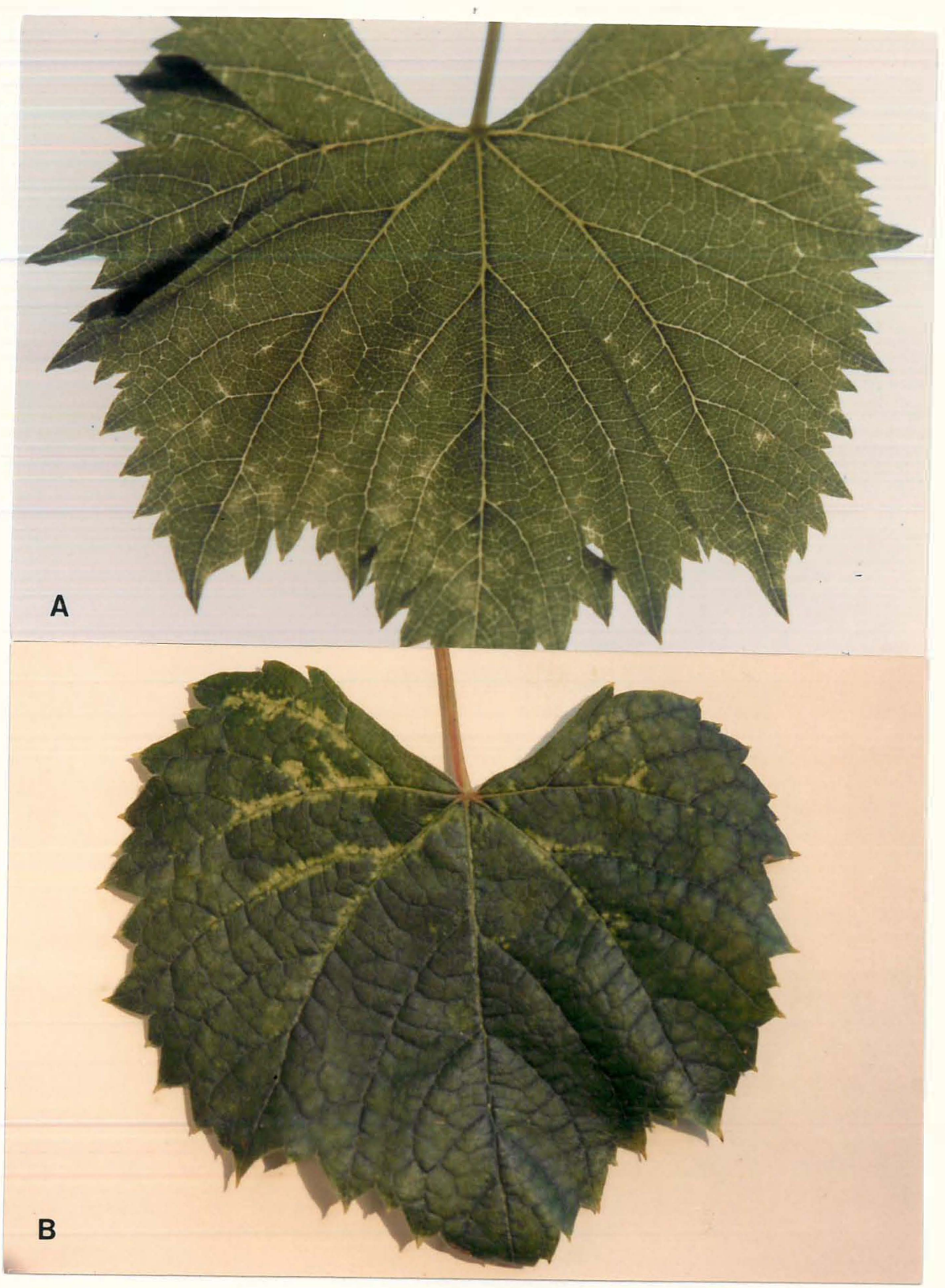

Figura 2. Sintomas induzidos pelo vírus do mosaico das nervu ras. A - Folha jovem da variedade Kioho com pali= dez das nervuras menores. B - Folha madura de Kio ho com amarelecimento do parênquima adjacente a a gumas nervuras principais e secundárias. 


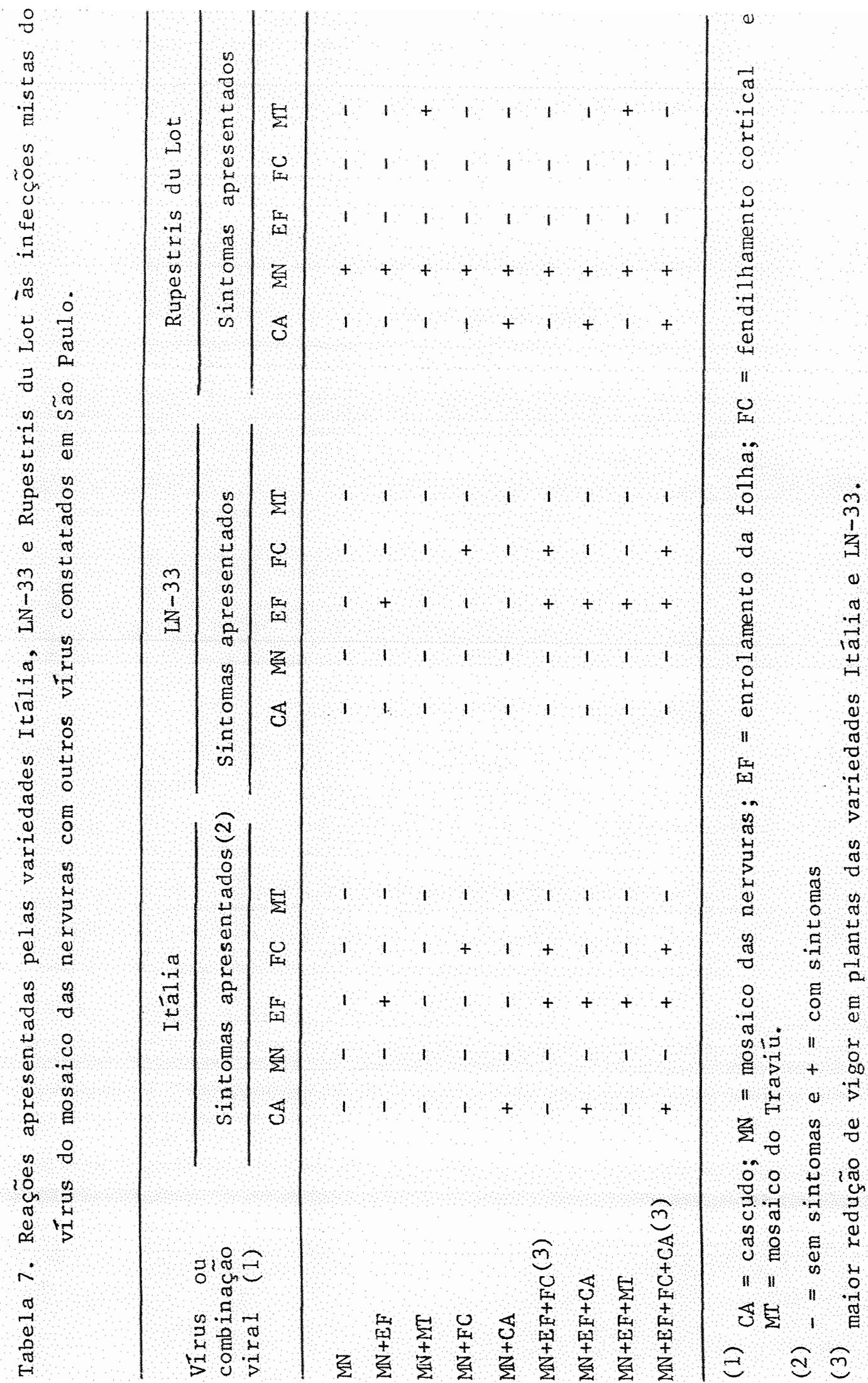




\subsubsection{Sintomas do mosaico das nervuras em porta-enxertos}

Dos porta-enxertos examinados, apenas 3 foram capazes de exibir sintomas nítidos do mosaico das nervuras: Golia, Kober 5BB e Rupestris du Lot.

Os sintomas em plantas infetadas de Rupestris du Lot consistem de manchas cloróticas de pequenos comprimentos das nervuras de terceira e quarta ordens e äreas adja centes do limbo, constituindo um mosaico das nervuras (Figura $3, A)$, donde o nome dado à virose. Apresentam ainda super ficie ondulada e ligeira curvatura dos bordos para cima. Esses sintomas manifestam-se com intensidade nas folhas jovens e médias da brotação de primavera. o nūmero dessas manchas cloroticas em cada folha e o numero de fol has com sintomas em cada planta são bastante variáveis. Nas condições de cam po, o mosaico das nervuras pode ser facilmente visto em plan tas infetadas e não enxertadas desse porta-enxerto ou nas suas brotações espontâneas de combinações enxertadas. Essas manchas persistem pouco tempo, pois desaparecem a medida que as fol has vão se tornando maduras e a temperatura vai se ele vando como decorrer do tempo; e não mais aparecem nas foIhas das novas brotações do mesmo ciclo vegetativo. Sob condiçóes de são paulo, o melhor período para observação de sín tomas corresponde aproximadamente aos meados de agosto a mea dos de outubro, estando o aparecimento de sintomas dentro desse intervalo em função de a brotação de primavera ser pre coce ou tardia.

o porta-enxerto Golia apresenta sintomas idên ticos aos do Rupestris du Lot. o cavalo 5 BB também mostra sintomatologia parecida à dos dois porta-enxertos

( Fi gura 3, B), mas, em casos severos, as fol has tornam-se as simétricas, as manchas tornam-se maiores e apresentam bordos cloróticos. 


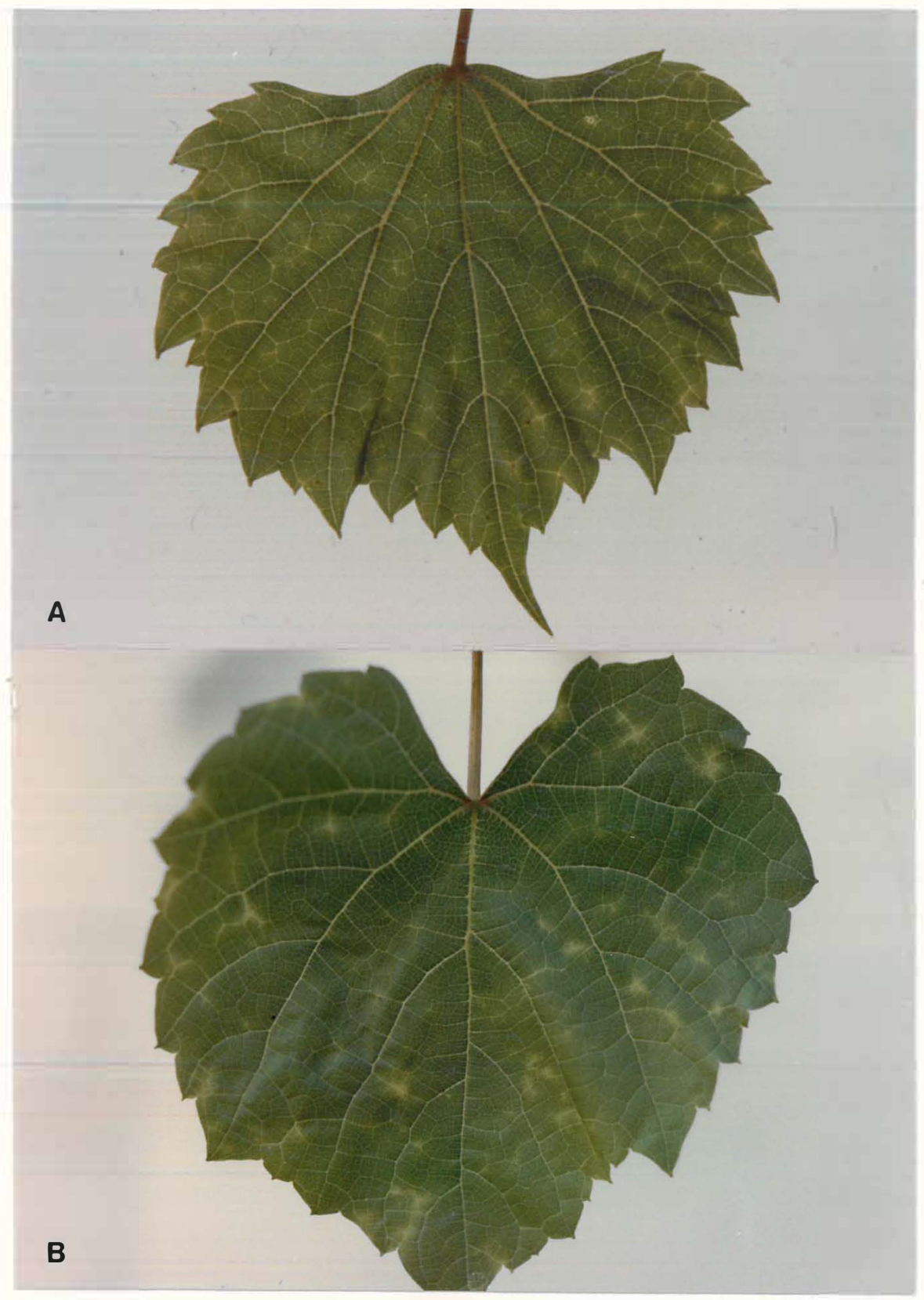

Figura 3. Sintomas de palidez das nervuras induzidos pelo ví rus do mosaico das nervuras. A - Folha do porta-eñ xerto Rupestris du Lot. B - Folha do porta-enxer= to Kober $5 \mathrm{BB}$. 
Nos outros cavalos examinados, como o Traviū, IAC 313 , IAC 766, 420A, 101-14, etc., não foram notados sintomas de infec ção pelo vírus do mosaico das nervuras.

\subsubsection{Anomalias de outras caus as com sintomas} semelhantes aos da virose mosaico das nervuras

Durante o desenvolvimento das investigações sobre o mosaico das nervuras, algumas anomalias foram reconhecidas como apresentando sintomas que poderiam causar confusão com os da virose em estudo. Os fatores causadores des sas anomalias foram os seguintes: (a) infecção inicial pelo fungo causador da antracnose Elsinoe ampelina (De Bary) She ar, principalmente nas folhas novas; (b) danos por picadas de in setos, provave 1 mente tripes, que resultam em numerosas pon tuações transiúcidas, principalmente nas folhas novas e médias das partes mais sombreadas; (c) infecção pelo vírus do mosaico do Traviú nos porta-enxertos kober 5 BB e Rupestris du Lot (Figura 4,A), que reagem à infecção através de numero sas pontuaçóes trans lúcidas; (d) danos de inseticidas e herbicidas; (e) danos de alimentação do ácaro branco (Polyphago tarsonemus Latus) e rajado (Tetranychus urticae); (f) toxemia resultante de alimentação por formas jovens da cochonilha Parassaissetia nigra (Figura $4, \mathrm{~B}$ ) e (g) fatores de natureza genética, que provocam clareamento de algumas nervuras menores.

\subsection{VIDEIRAS INDI CADORAS}

Como a grande maioria das variedades de copa e de porta-enxerto cultivadas ou mantidas no Estado de são Paulo não exibe sintomas perceptíveis do mosaico das nervuras, verificou-se que o emprego de videiras indicadoras é in dispensável para a diagnose da moléstia. Em são paulo, 


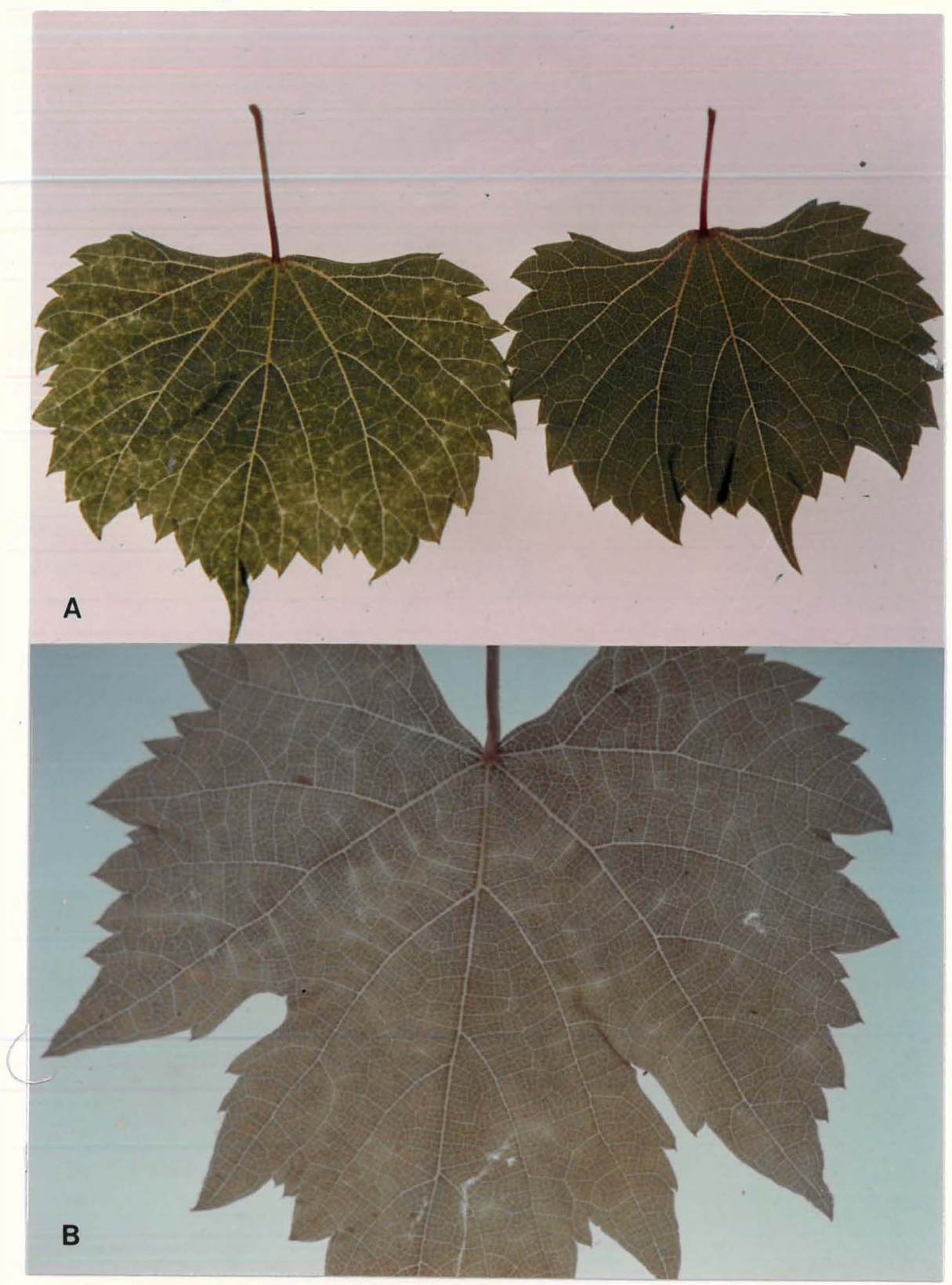

Figura 4. Sintomas associados a outras causas que podem ser confundidos com os do mosaico das nervuras. A - Fo 1 ha de Rupestris du Lot com pontuações translúcidas induzidas pelo vírus do mosaico do Traviú ao 1 ado de uma sadia. B - Folha da variedade Itália com palidez das nervuras associada à cochonilha Pa rassaissetia nigra. 
porta-enxertos podem ser utilizados como indicadoras do mosaico das nervuras, pois exibem sintomas evidentes da moléstia quando infetadas pelos isolados comuns. São eles o Rupestris du Lot, que jā é indicadora do "grapevine fleck disease", o Kober 5BB e o Golia. Contudo, notou-se que eles náo se comportam igualmente, quando ocorrem variaçóes ambien tais. Assim sendo, comparações e observações foram feitas no sentido de esclarecer esses fatos para tornar os testes diagnósticos mais eficientes. Aproveitou-se a oportunidade para também verificar se um desses porta-enxertos poderia se sobressair do ponto de vista da sintomatologia e sensibilidade ao vírus e consequlentemente, poderia ser rotineiramen te usado para padronização dos estudos experimentais.

\subsubsection{Comparação de videiras indicadoras infetadas com 3 isolados do vírus do mosaico das nervuras e mantidas dentro e fora de casa de vegetação}

Logo no início das investigações, observou-se que as plantas indicadoras do mosaico das nervuras mantidas dentro de casa de vegetação não manifestavam sintomas nítidos da virose ou muitas delas simplesmente não os exibiam. plantas comparáveis que tinham sido colocadas ao ar livre deram resultados mais confiàveis.

Com o objetivo de melhor verificar esse tipo de reação, grupos comparäveis de plantas bem estabelecidas em vasos das indicadoras Golia, Kober 5BB e Rupestris du Lot in fetadas pelos isolados comuns e de kioho foram mantidos dentro e fora de casa de vegetação, em experimentos realizados em 1977, 1978 e 1979. Um isolado fraco foi adicionado a par tir de 1978. Os resultados, que são encontrados na tabela 8 , mostram que a porcentagem de plantas comsintomas foi bas tante alta para o grupo das indicadoras mantidas fora de 


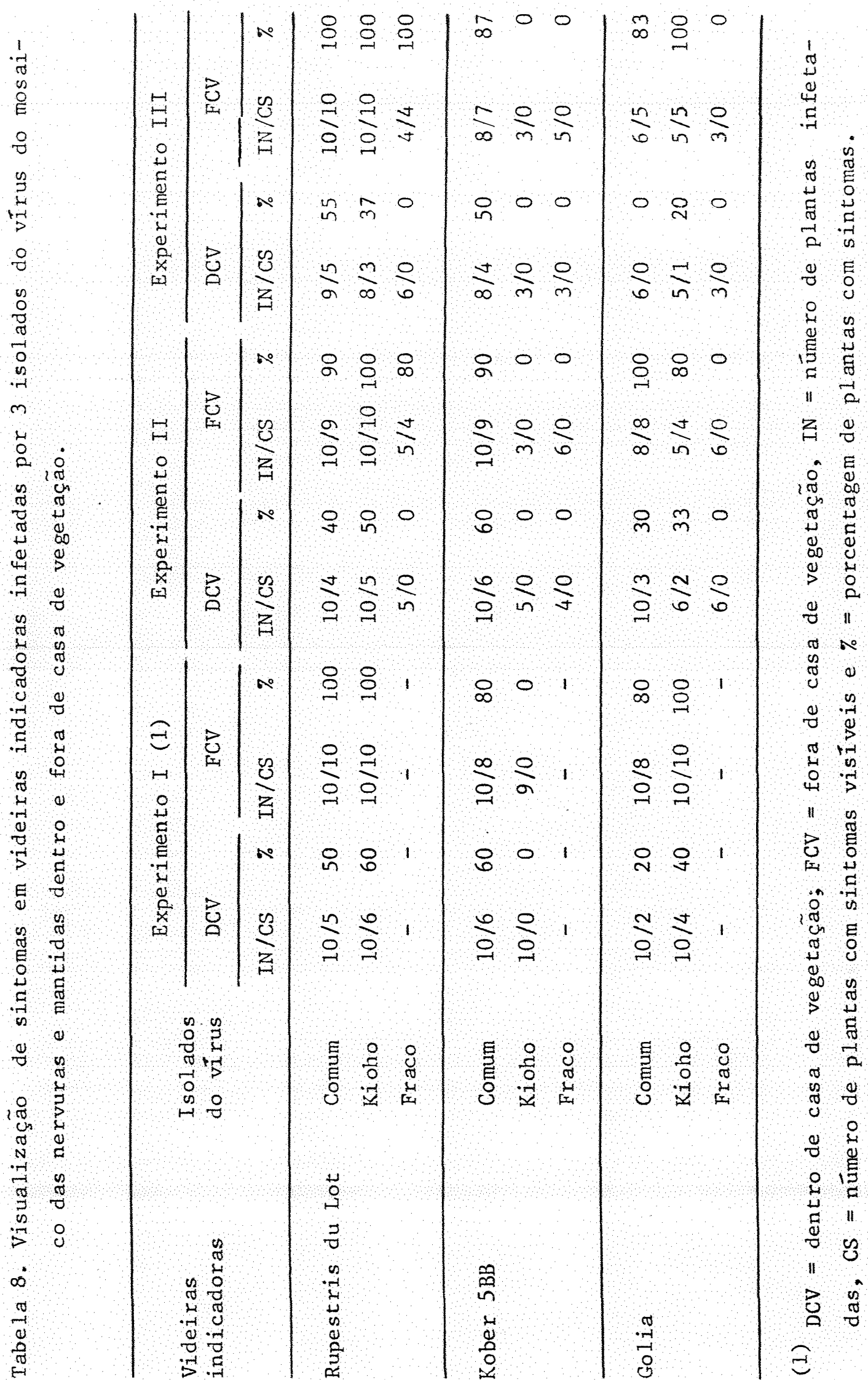


casa de vegetação, principalmente das infetadas pelos isolados comuns e de Kioho. As plantas de Kober 5BB, mantidas tanto dentro como fora de casa de vegetação, não reagiram com sintomas visíveis à infeção pelos isolados de Kioho. Foi notado que os sintomas de todas as plantas de Rupestris du Lot infetadas pelos isolados de Kioho apareceram mais pre cocemente, eram mais fortes e persistiram por mais tempo do que os induzidos pelos isolados comuns. Algumas plantas das 3 indicadoras não manifestaramsintomas nas leituras feitas em cada ano, pois a sua brotação de primavera se deu comatra so, ultrapassando como consequência a época adequada para o aparecimento das reaçós. 0 isolado fraco somente induziu o aparecimento de sintomas em Rupestris du Lot mantido fora de casa de vegetação.

\subsubsection{Outros fatores que podem influir na manifestação de sintomas em indicadoras mantidas ou colocadas fora de casa de vegetação}

Além do efeito positivo na manifestação de sin tomas do mosaico das nervuras quando as plantas indicadoras foram mantidas para crescimento fora de casa de vegetação, os seguintes resultados de observaçoes foram obtidos para plantas de Kober 5BB e principalmente de Rupestris du Lot, por sereste o mais utilizado:

a) as 2 variedades de videira manifestaram tomas nitidos em quase todas as plantas infetadas, quando a brotação de primavera se processou dentro de um período de temperatura amena; além disso, quando sobreveio um período de temperatura amena de alguns dias, seja no fim de primavera ou no verão, foi observado que as plantas que estavam em crescimento vigoroso, principalmente aquelas plantadas diretamente no solo, exibiram sintomas perceptíveis; 
b) em determinados anos, foi verificado que muitas plantas infetadas das indicadoras não exibiramsintomas, pois as folhas logo se tornaram rígidas e amareladas. Em geral, isso ocorreu quando o desenvolvimento dos ramos novos da brotação de primavera coincidiu com periodo longo de temperatura alta. Notou-se tambēm que muitas plantas não apre sentaram sintomas, quando a brotação de primavera se deu com atraso;

c) durante a ocorrência desse período de temperatura alta, observou-se que as plantas de estaca enraizadas, inoculadas e colocadas fora de casa de vegetação no mes mo ano foram mais sensíveis às condições adversas do ambiente, pois geralmente não apresentaram sintomas devido ao menor crescimento vegetativo. Por outro lado, as videiras bem estabelecidas em vasos e que jā se encontravam no mínimo no segundo ciclo vegetativo após a enxertia de inoculação foram capazes de exibir sintomas nítidos. De modo semelhante, as plantadas diretamente no solo hà 2 anos no mínimo também deram bons resultados;

d) folhas de ponteiro das brotações axilares ou resultantes da poda do ramo inicial das indicadoras infetadas geralmente não apresentaram sintomas ou então, exibiramapenas em pequeno número de plantas e combaixa intensidade;

e) indicadoras infetadas em início de brotação de primavera ou jā brotadas, ambas em condições de casa de vegetação, não apresentaram sintomas quando colocadas fora de estufa, pois logo sofreram queimaduras e as novas folhas adquiriram aspecto rígido e coloração amarelada;

f) videiras indicadoras infetadas crescendo em vasos pequenos ( $150 \mathrm{~mm}$ de diâmetro e $160 \mathrm{~mm}$ de altura) fora 
de casa de vegetação não deram bons resultados, pois o desenvolvimento das mesmas foi reduzido e as folhas logo atingiram a maturação. Ao contrário, aquelas mantidas em recipientes grandes (sacos plásticos de $280 \mathrm{~mm}$ de diâmetro e 350 mm de altura ou maiores) ou plantadas diretamente no solo, geralmente apresentaram bons resultados;

g) indicadoras preparadas a partir de estacas com diâmetro menor do que $5 \mathrm{~mm}$ geralmente não apresentaram bons resultados nos testes de indexação no mesmo ano que foram colocadas fora de casa de vegetação. Isso por que o desenvolvimento dessas plantas foi bastante reduzido. o mesmo ocorreu com estacas de diâmetro maior do que $20 \mathrm{~mm}$.

\subsubsection{Tentativas visando induzir o aparecimento de sintomas do mosaico das nervuras nas indicadoras após a brotação de primavera}

Devido ao fato de as videiras indicadoras mani festarem sintomas do mosaico das nervuras apenas nas folhas de brotação de primavera e de modo transitório, a diagnose da moléstia só pode ser feita uma vez por ano e durante curto periodo de tempo. Quando se torna impossivel reconhecer os sintomas devido às adversidades climáticas, a obtenção de re sultados é deixada para a brotação de primavera do ano seguinte. Procurou-se então verificar a possibilidade de forçar a manifestação de sintomas nas indicadoras infetadas fora da época normal.

Na Tabela 9 , são encontrados os resultados obtidos, quando plantas vígorosas e bemestabelecidas em recipientes grandes dos porta-enxertos Kober 5 BB e Rupestris du Lot, anteriormente infetadas pelos isolados comuns do vírus do mosaico das nervuras e com novos crescimentos após a poda dos ramos da brotação de primavera, foram submetidas a 





diferentes combinações de 1 uz e de temperatura, durante os meses de janeiro e fevereiro de 1988. Observa-se que as plan tas mantidas em casa de vegetação e depois em câmara deram resultados totalmente negativos. Quando as plantas dos 2 porta-enxertos foram colocadas apenas em câmara ou sob condi ções de laboratório, apenas 1 planta de Rupestris du Lot de cada tratamento mostrou sintomas da moléstia. Resultados pó sitivos foram conseguidos quando as plantas foram mantidas dentro de cámara e depois colocadas ao ar livre, sendo me thor à sombra do que ao so1. Dentre os tratamentos testados, os me thores resultados for am conseguidos quando as indicadoras apenas cresceram ao ar 1 ivre, porém à sombra. Em todos os casos positivos, os sintomas foram sempre mais fracos do que os costumeiramente observados em folhas de brotação de prima vera. Notou-se também que as folhas adquiriram coloração amare 1 ada aos $10-12$ dias, quando as videiras foram colocadas dentro de câmara a $200 \mathrm{C}$ e sob 12 a 14 horas de 1 uz, fornecida por 2 lámpadas fluorescentes de 40 W, do tipo do dia, situadas a 3 metros das plantas. Considerando a soma das plan tas de todos os tratamentos, para os 2 porta-enxertos, onumero de plantas com sintomas fol maior em Rupestris du Lot do que em kober 5BB. Da mesma forma, o número de plantas que exioiram sintomas dos 2 porta-enxertos foi maior em janeiro do que em fevereiro.

\subsection{Etiologia}

\subsubsection{Perpetuação}

0 vírus do mosaico das nervuras se perpetua invariavelmente através da propagação vegetativa. Isso foi demonstrado em todos os casos em que foi feita a propagação de plantas infetadas, sejam de variedades que mostram sintomas (Golia, kober 5 BB e Rupestris du Lot), como daquelas 
que não os exibem (Isabel, Itälia, Niagara Rosada, Seibel 2 , Traviū, 420A, etc.). Foi verificado tambēm que esse fenômeno não depende do método de multiplicação e do tamanho e maturação da parte da videira empregada para esse propósito.

\subsubsection{Transmissibilidade}

As seguintes maneiras de transmissão natural e experimental foram consideradas, para estudar a epidemiologia do vírus do mosaico das nervuras.

\subsubsection{Transmissão por união de tecidos}

Foi comprovado que o vírus do mosaico das ne vuras é facilmente transmitido e recuperado por diferentes mé todos de união de tecidos, tais como garfagem, encostia, enxertia de gema inóculo ou da indicadora, dupla-enxertia de gema, etc. A transmissibilidade do vírus não dependeu do método de enxertia e do tamanho e maturação da parte da videira empregada para enxertia. Na Tabela 10, são encontra dos os resultados dos testes de transmissão mediante enxer tia de gemas de plantas infetadas de al gumas variedades de copa e de porta-enxerto em plantas sadias dos cavalos Golia, Kober 5BB e Rupestris du Lot. Todas as plantas inoculadas fo ram infetadas pelo vírus. Contudo, plantas de Kober $5 B B$ enxertadas com material propagativo das variedades kioho e olim pia não exibiram sintomas de mosaico das nervuras, embora o vírus tivesse sido recuperado com facilidade para a videira indicadora Rupestris du Lot, pois induziram sintomas caracteristicos de palidez das nervuras menores.

Nesses testes, foi verificado que os sintomas do mosaico das nervuras não se manifestaram de maneira conspicua nas folhas dos ramos desenvolvidos por muitas plantas das indicadoras ainda no mesmo ciclo vegetativo em que foi 
Tabela 10. Transmissão do virus do mosaico das nervuras pela enxertia de gema de plantas infetadas de diferentes variedades de videira em 3 porta-enxertos que exibem sintomas da moléstia.

Videiras fontes de vírus e controle
Número de plantas inoculadas e infetadas das videiras indicadoras abaixo
Golia

In fetadas

$\begin{array}{llll}\text { IAC 138-22 } & 5 / 5 & 5 / 5 & 3 / 3 \\ \text { Itália } & 5 / 5 & 5 / 5 & 5 / 5 \\ \text { Ittälia Rubi } & 5 / 5 & 5 / 5 & 3 / 3 \\ \text { Niagara Branca } & 5 / 5 & 5 / 5 & 5 / 5 \\ \text { Seibel 2 } & 5 / 5 & 5 / 5 & 3 / 3 \\ \text { Seyve Villard 5276 } & 5 / 5 & 5 / 5 & 3 / 3 \\ \text { Kioho } & 5 / 5 & 5 / 5(1) & 3 / 3 \\ \text { Olimpia } & 5 / 5 & 5 / 5(1) & 3 / 3 \\ \text { Kober 5BBB } & 5 / 5 & 5 / 5 & 5 / 5 \\ \text { Rupestris du Lot } & 5 / 5 & 5 / 5 & 5 / 5 \\ \text { 420A } & 5 / 5 & 3 / 3 & 2 / 2\end{array}$

\section{Sadias}

Itâlia

Kioho

Niagara Branca

Seyve Villard 5276

kober $5 \mathrm{BB}$

Rupestris du Lot

$420 \mathrm{~A}$
$5 / 0$

$5 / 0$

$3 / 0$

$5 / 0$

$3 / 0$

$3 / 0$

$3 / 0$
$5 / 0$

$3 / 0$

$3 / 0$

$3 / 0$

$3 / 0$

$3 / 0$

$3 / 0$

$3 / 0$

$3 / 0$

$2 / 0$

$3 / 0$

$2 / 0$

210

$2 / 0$

(1) As plantas inoculadas de Kober 5BB näo exibiram sintomas quando enxertadas com material de Kioho e olimpia, mas estavam infetadas de acordo com testes de recuperação empregando o porta-enxerto Rupestris du Lot. 
feita a enxertia, mas tornaram-se bastante evidentes

nas brotaçóes de primavera dos anos subsequentes. Na Tabela 11 , estão apresentados os resultados em que se procurou verificar o efeito dos diferentes métodos de enxertia na manifesta ção dos sintomas da moléstia na indicadora Rupestris du Lot. Verifica-se que a enxertia de gema herbácea da indicadora e a dupla-enxertia, que consistiu na enxertia de uma gema indicadora e de uma gema inóculo em uma mesma videira sadia, apresentaram resultados superiores aos dos outros métodos tes tados no mesmo ano da enxertia; mas, a porcentagem de plan tas com sintomas foi baixa, no mäximo $20 \%$, em relação ao número de plantas inoculadas. A garfagem de brotos de 50 a 100 $\mathrm{mm}$ e a encostia deram resultados negativos. As enxertias de gemas de plantas infetadas em indicadoras também deram resul tados pouco satisfatórios, com apenas $8 \%$ de plantas com sintomas. Mas todos os métodos apresentaram a mesma eficiência ou seja, todas as plantas inoculadas mostraram sintomas independente do método de enxertia a partir da brotação orinada depois do primeiro inverno.

Não foi verificado um único caso de transmissão do yírus, quando houve apenas contato físico entre tecido sadio e infetado, devido ao não pegamento das enxertias.

Não foram executados testes para verificar a eficiência dos diferentes métodos de enxertia quanto ao pega mento. Entretanto, foi verificado através dos anos que as técnicas de enxertia de brotos de 50 a $100 \mathrm{~mm}$ de comprimento por garfagem e a enxertia de gemas, herbäceas ou dormentes, de plantas infetadas ou a serem testadas em videiras indicadoras ofereceram porcentagens de pegamento de 80 a $90 \%$ e até $100 \%$, quando as operaçóes foram executadas em épocas apropriadas (agosto a fevereiro). 







\section{5 .2 .2 . Ligações com cuscuta}

Nove plantas da indicadora Rupestris du Lot foram unidas complantas da variedade Itália infetada pelo virus do mosaico das nervuras por meio de cuscuta, durante todo o ciclo vegetativo desta (cerca de 50 dias), mas não fo ram observados sintomas de infeç̧ão durante 2 anos de observaçóes. A cuscuta utilizada, que pertence a uma es pécie não identificada mas comumente encontrada em cercas vivas, apre sentou bom desenvolvimento vegetativo quando colocada em videira.

\subsubsection{Tentativas de inoculação mecânica}

Várias tentativas foram feitas no sentido de verificar se o vírus do mosaico das nervuras é transmissível por inoculação mecänica. Centenas de plantas de 35 espé cies herbáceas e das videiras kober 5 BB e Rupestris du Lot foram inoculadas através de friç̧ão do inóculo na superfície das folhas previamente polvilhadas com carborundo, mas nenhu ma apresentou sintomas de infecção.

Os resultados também foram totalmente negati vos, quando numerosas plantas herbáceas e das videiras indicadoras kober 5BB e Rupestris du Lot foram inoculadas através de 4 outros métodos, chamados de pica-couve e pseudo-encostia es baseados em cortes com lâmina contaminada e na deposição do inóculo na superfície cortada.

\subsubsection{Transmissão pe 1 a semente}

Foi testado um total de 340 plantas originárias de sementes colhidas de videiras sabidamente infetadas de 4 yariedades de copa (IAC $138-22,28$ p 1 antas de semente; Itália, 60 ; Kioho, 10 e Seyve Villard 5276,42 ) e de 2 por- 
ta-enxertos (Golia, 100 e Kober 5BB, 100). O Rupestris du Lot não foi testado por que não produz sementes.

Não foi notado nenhum sintoma que sugerisse transmissão do vírus nas plantas de semente de Golia e kober $5 B B$, depois de 2 a 3 anos de observações. Quando clones resultantes da propagação vegetativa de 10 plantas de semente de kober $5 \mathrm{BB}$ e 20 de Golia foram inoculados com o vírus do mosaico das nervuras, houve manifestação de sintomas característicos da virose, ao passo que as plantas de onde se ori ginaramesses clones permaneceram sem alteração. Resultados dos testes de indexação das plantas de semente das 4 variedades de copa acima mencionadas foram negativos.

Dentre as plantas de semente obtidas das videiras testadas, algumas mostraram ser pouco vigorosas ou apresentaram anomalias foliares, tanto na forma como na pigmentação. Testes de transmissão feitos mediante enxertia de gemas de 3 plantas anómalas de Itália, 2 de kioho e 5 de Golia em plantas sadias das respectivas variedades deram resul tados negativos.

\section{5 .2 .5$. Vetor}

Embora o vírus do mosaico das nervuras ocorra comalta incidência dentro dos vinhedos paulistas, a existência de disseminação por melo de vetor ainda não foi obser vada até o momento. Além disso, devido ao fato de as principais variedades de copa e de porta-enxerto não apresenta rem sintomas visíveis, torna-se difícil essa determinaçáo. Procurou-se entäo fazer observaçôes no sentido de obter algumas informações a esse respeito.

Na Estação Experimental de São Roque do Insti tuto Agronómico de Campinas, foram encontradas plantas $1 \mathrm{i}-$ 
vres do virus do mosaico das nervuras dos porta-enxertos Golia, Kober 5BB, Rupestris du Lot e Traviü, através de testes de indexação. Essas plantas tinhamentre 20 a 30 anos de idade na época da coleta de material propagativo em 1971 . observações feitas naquelas plantas de Golia, kober $5 B B$ e Ru pestria du Lot e testes de indexação em 3 plantas de Traviū, ainda existentes em 1982, não permitiram detectar casos de infecção. Além disso, em 1978, verificou-se que apenas 1 clone de 4 testados de Niagara Branca, originados de material propagativo estabelecido em 1928 nessa Estação, achava se infetado pelo vîrus. Um clone de Isabel, também resultan te de material estabelecido em 1928, também encontrava-se li vre do virus.

Em Ferraz de Vasconcelos, foi encontrada em 1973, uma planta bastante antiga de Kober 5BB, com mais de 40 anos de idade segundo alguns viticultores da região, que não exibia sintomas do mosaico das nervuras, embora rodeada por plantas de uva Itália infetadas pelo vírus, conforme tes tes posteriores de indexação. Suas propagações também não mostraram sintomas.

Em um vinhedo de São Roque, observações feitas de 1973 a 1979 em 3 plantas de Rupestris du Lot sem sintomas não permitiram notar evidências de transmissão natural do vírus. Essas plantas cresciam em meio a uma plantação de Niagara Branca enxertada no mesmo cavalo, onde a grande maí ria das brotações espontâneas desse porta-enxerto costumava exibir sintomas da virose.

Ao longo dos vários anos de estudos sobre o mosaico das nervuras na Seção de Virologia do Instituto Agro nômico de Campinas, não foi notado um ünico caso que sugeris se transmissão do vírus por meio de vetor entre as plantas a dias de Rupestris du Lot mantidas por 3,5 ou até mais anos, 
em meio a numerosas plantas infetadas desse mesmo porta-enxerto.

4.5.3. Tentativas de visualização de particulas seme lhantes a vírus ao microscópio electrônico

Preparações rápidas pelo método "leaf dip" e seç̧ós ultrafinas de folhas e brotos de Rupestris du Lot com sintomas do mos aico das nervuras, quando submetidas a observaçóes ao microscópio electrônico, não permitiram notar particulas virais, inclusöes e nem alteraçöes de natureza ci topatológica. Esses exames foram feitos pelo especialista Jor ge Vega, da Seção de Virologia do Instituto Agronómico de Cam pinas.

\subsubsection{Isolados do vírus do mosaico das nervuras}

\subsubsection{Isolados das variedades kioho e 01 impia}

Durante os estudos de transmissão do vîrus por uniáo de tecidos, foi verificado que plantas do portaenxerto kober 5 BB não manifestaram os sintomas esperados da virose, quando enxertadas com material propagativo das varie dades kioho e Olimpia, embora estivessem infetadas. Esses re sultados sugeriram a existência de 2 isolados diferentes do vírus do mosaico das nervuras. Testes comparativos foram feitos no sentido de verificar esse fato.

Primeiramente, foram executados experimentos de inoculação por união de tecidos para verificar a relação entre os vírus presentes nas variedades kioho e 01 impia. Na Tabela 12 são encontrados os resultados obtidos da enxertia de 3 a 5 plantas sadias por variedade testada com brotos de 50 a $100 \mathrm{~mm}$ de comprimento por garfagem ou com gemas herbá- 


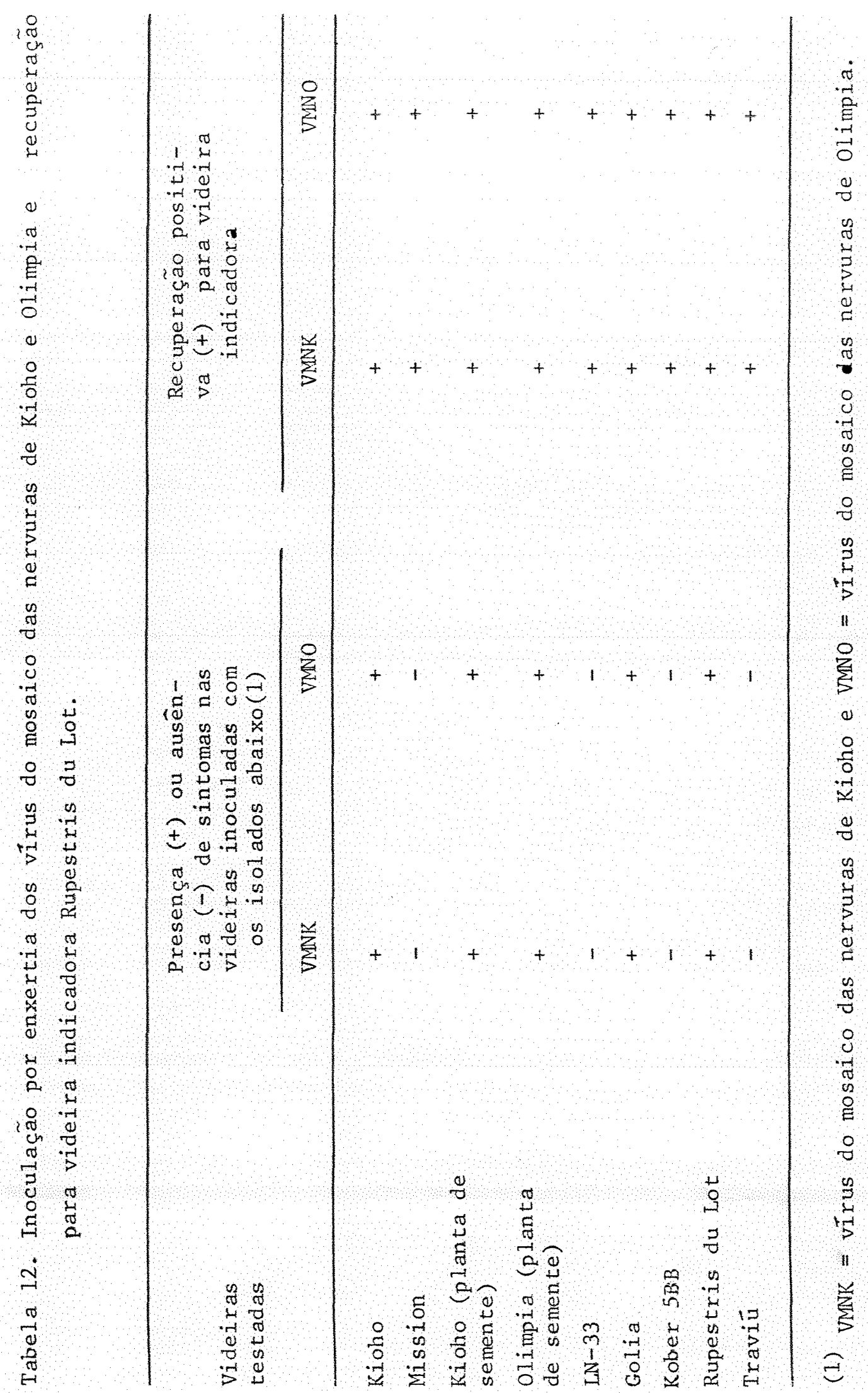


ceas ou dormentes de videiras infetadas pelos 2 virus. Mostram que todas as variedades de copa e de porta-enxerto inoculadas comportaram-se de modo igual para ambos os vírus.

Compararam-se a seguir o isolado presente na variedade kioho e isolado comum do vírus do mosaico das nervuras. Na Tabela 13 encontram-se os resultados da inoculação dos 2 isolados em plantas de 9 variedades de copa e de 10 porta-enxertos, através dos métodos de garfagem de brotos e da enxertia de gemas herbáceas ou dormentes. Foram empregadas 3 a 5 plantas por variedade e para cada isolado. Poucas diferenças foram detectadas. A variedade kioho não mostrou sintomas, quando infetada pelo vírus do mosaico das ner vuras de ocorrência comum. 0 cavalo kober 5 BB exibiu sintomas apenas para o isolado comum, enquanto o Golia e o kupestris du Lot apresentaram sintomas quando infetados por ambos. A variedade Seyve villard 5276 mostrou folhas cloróti cas e palidez de algumas nervuras para o isolado comum; para o de Kioho, apresentou sintomas fracos de clorose foliar e de palidez de algumas poucas nervuras menores, mais fáceis de distinguir quando observada ao lado de plantas sadias. o por ta-enxerto $5 \mathrm{C}$ mostrou palidez de algumas nervuras menores de a loumas folhas novas, mas não foi visível em todas as brotações de primavera. Os resultados dos testes de recuperação, feitos em 1 ou 2 plantas por variedade, foram positivos em todos os casos.

Diante dos resultados obtidos, considerou - se a hipótese de que o isolado comum e de kioho seriamestirpes de um mesmo vírus, sendo diferenciadas através da sintomatologia apresentada por plantas de Kioho e kober 5 BB. Para verificar essa possível relação de parentesco, testes foramefe tuados, em que plantas de Kioho, Kober 5 B B e Rupestris du Lot previamente infetadas pelos isolados comuns, de Kioho e de olimpia, foram submetidas a superinoculação com cada um des- 
Tabela 13. Inoculação por enxertia dos isolados comuns e de Kioho do vi rus do mosaico das nervuras em variedades de copa e de portaenxerto e recuperação paravideira indicadora Rupestris du Lot.

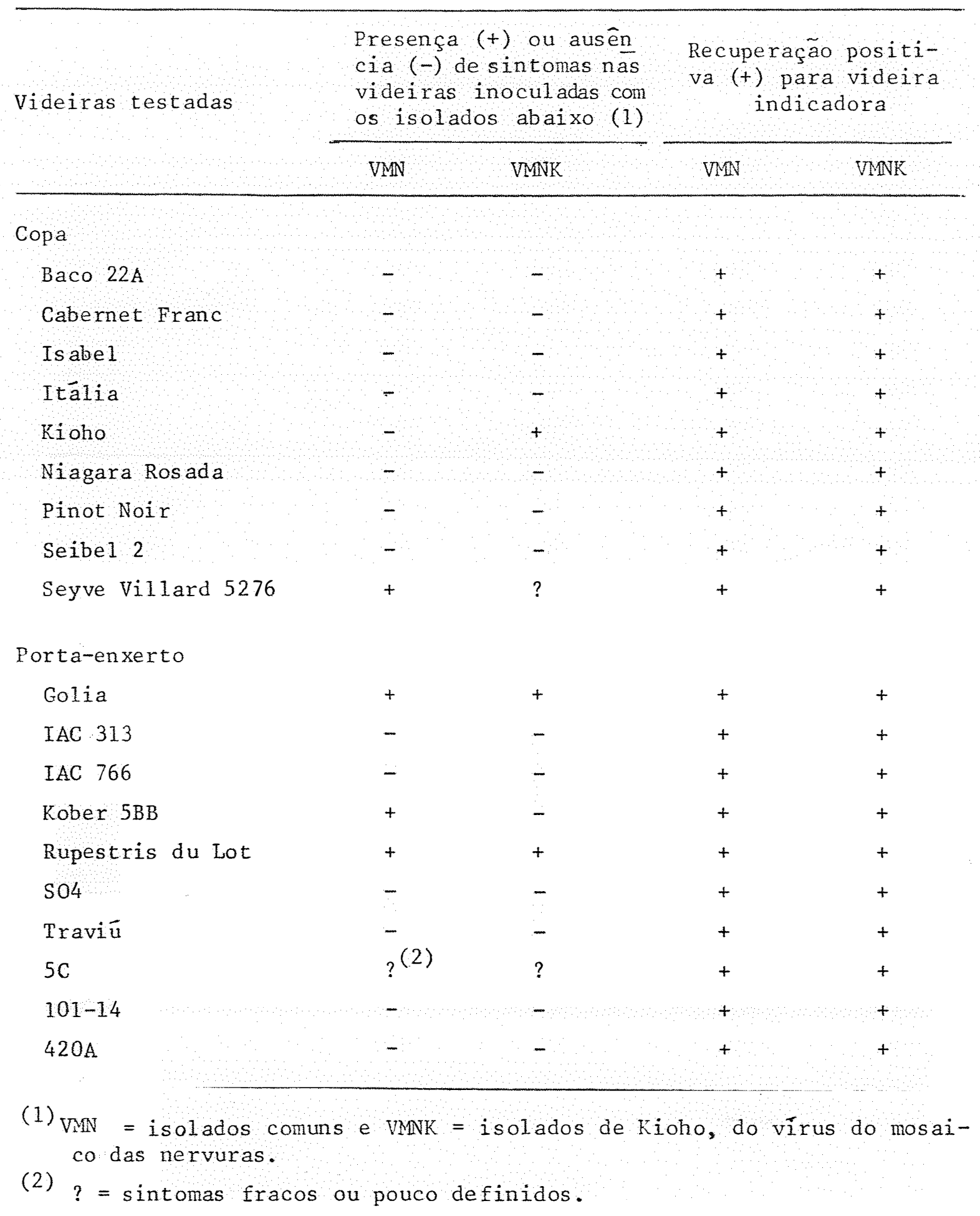


ses. Todas as inoculações foram feitas através de enxertia de gema, herbácea ou dormente. Os resultados obtidos depois de 3 a 4 anos de observações, al gumas por mais de 6 anos, en contram-se na Tabela 14. Permitem observar que as plantas de Kober 5BB premunizadas com isolados comuns e superinocu ladas com os de kioho e de 01 impia continuaram a apresentar sintomas de palidez das nervuras ou então, não apresentaram sintomas. Em plantas de Kober 5 B B premunizadas com os isolados de kioho e de olimpia e superinoculadas com os comuns, não foram observados sintomas aparentes. A variedade kioho não exibiu sintomas que sugerissem interação entre os isolados. Todas as plantas de Rupestris du Lot apresentaram sintomas de palidez das nervuras. Testes de recuperação feitos em algumas plantas de Kober 5BB, inoculadas com os isolados de Kioho e de 01 impia e superinoculadas com os comuns, que não deramsintomas, permitiram observar palidez das nervuras em Rupestris du Lot.

\subsubsection{Isolado fraco do vírus do mosaico das nervuras obtido de planta da variedade Itälia}

Em material propagativo de uma planta da variedade Itália de São Mi guel Arcanjo (propriedade do sr. F. Hayashi), coletado em 1972, foi obtido um isolado do vírus do mosaico das nervuras que, ao ser inoculado na indicadora Rupestris du Lot, induziu sintomas fracos de palidez das nervuras menores. 0 número de manchas cloróticas por folha e o número de folhas com sintomas por planta da indicadora foi bem menor do que as induzidas pelos isolados comuns do mesmo virus. Esse tipo de sintoma foi constante em Rupestris du Lot durante vários anos de observações. Não foram notados sintomas em plantas inoculadas de Golia e de Kober 5BB.

Plantas resultantes de estaca dessa uva Itá- 
Tabela 14. Réações obtidas nos testes de proteção para verificar a relação entre os isolados comuns e os de Kioho e Olimpia do vírus do mosaico das nervuras.

Videiras inoculadas previamente com os isolados abaixo (1)
Número de plantas testadas com pegamento da enxer tia, presença $(+)$ ou ausência $(-)$ de sintomas nas videiras inoculadas por enxertia de gema com os isolados desafiantes

\begin{tabular}{ccc} 
VMN & VMNK & VMNO \\
No de Sinto & No de sinto & No de sinto \\
plantas mas & plantas mas & plantas mas \\
\hline
\end{tabular}

Kioho/VMN

Kioho/VNMK

Kober $5 \mathrm{BB}$

Kober $5 \mathrm{BB} / \mathrm{NMN}$

Kober $5 \mathrm{BB} / \mathrm{VNMK}$

Kober $5 \mathrm{BB} /$ VMNO

Rupestris du Lot

Rupestris du Lot/VMN

Rupestris du Lot NMNK

Rupestris du Lot/VMNO

$\begin{array}{rrrrrrr}2 & - & 5 & + & 4 & + \\ 5 & + & 1 & + & 3 & + \\ 10 & + & 10 & - & 10 & - \\ 9 & + & 5 & -1+(2) & 5 & -1+(3) \\ 21 & - & 13 & - & 9 & - \\ 25 & - & 8 & - & 5 & - \\ 5 & + & 5 & + & 5 & + \\ 5 & + & 9 & + & 5 & + \\ 10 & + & 4 & + & 6\end{array}$

(1) Plantas das yariedades kioho, kober 5BB e Rupestris du Lot previamente inoculadas com os isolados comms (VMN), de kioho (VNMK) e de olimpia (VMNO) do vírus do mosaico das nervuras.

(2) Duas plantas não apresentaram sintomas perceptiveis.

(3) Uma planta não apresentou sintomas perceptíveis. 
Iia, mantidas em casa de vegetação, não permitiram notar diferenças em vigor, quando comparadas com plantas infetadas por isolados comuns.

Em um pequeno teste, em que foram empregadas 4 a 5 plantas por tratamento, não foram observadas mudanças na resposta à infecção quando os porta-enxertos kober $5 B$ e e Rupestris du Lot, previamente infetados pelos isolados fraco e comuns, foram superinoculados com cada um desses. As plantas dos 2 porta-enxertos, inicialmente infetadas pelos isola dos comuns, continuaram a exibir sintomas de palidez das ner vuras, depois de superinoculadas com o isolado fraco. Da mes ma forma, as plantas de Rupestris du Lot infetadas pelo isolado fraco mostraram sintomas nítidos de palidez das nervuras, após terem sido superinoculadas com os isolados comuns. Nesse caso, as plantas infetadas de Rupestris du Lot apenas apresentaram sintomas de mesmo tipo. o porta-enxerto kober 5 BB, que não exibia sintomas da infecção de premunização pe10 isolado fraco, apresentou sintomas nitidos de palidez das nervuras, quando superinoculado com os isolados comuns.

\subsection{Controle}

Com base nos conhecimentos adquiridos até o presente, o vírus do mosaico das nervuras náo apresenta evidéncias de transmissão por vetor dentro dos vinhedos do Estado de sáo paulo. Diante disso e do fato de que a videira é planta perene de propagação vegetativa, considerou-se que o uso de clones sadios de variedades de copa e de porta - enxerto pode promover o controle da virose de modo bastante sa tisfatório. Dois métodos foram adotados para obtenção de clones livres do vírus do mosaico das nervuras: seleção de videiras sadias através de testes de indexação e limpeza de material propagativo através de medidas curativas. 
A seleção de plantas sadias através de testes de indexação é o primeiro recurso de que se lança mão, pois parte-se da hipótese de que ainda existem videiras livres de vírus nas condições de campo.

Resultados de testes empregando videiras indi cadoras feitos para 44 variedades de copa permitiram encontrar plantas isentas do vírus do mosaico das nervuras perten centes a 32 variedades, entre as quais Al phonse Lavallée, Ca bernet Franc, Concord, IAC 871-13 (A Dona), Isabe1, IAC $871-$ 41 (Patricia), Niagara Branca, Niagara Rosada e Seibe1.2. A grande maioria dessas videiras achava-se também infetada por outros vírus assinalados em são paulo, sendo possível a seleção de plantas sadias de apenas 5 variedades: IAC $842-4$ (Pi ratininga), IAC $514-6$ (Maria), IAC 871-13 (A Dona), Isabe 1

e SR 496-15 (Dr.Jüio). Com relação aos porta-enxertos, fó ram isolados clones livres do vírus do mosaico das nervuras e de outros registrados nos vinhedos paulistas de 12 varieda des: Golia, IAC 313 , IAC 572 , IAC 766 , Kober 5 BB, Rupestris du Lot, S04, 5C, 99R, 101-14, 106-8 (Traviu) e 420A.

\subsubsection{Medidas curativas}

São adotadas quando torna-se muito difícil en contrar plantas sadias nas condições de campo, tornando indispensável a eliminação de vírus do material propagativo in fetado.

As seguintes técnicas foram empregadas:

4.6.2.1. Termoterapia

Para as tentativas de 1 impeza de material pro 
pagativo de videiras infetadas através de tratamento de calor, 2 métodos foram estudados: (a) tratamento de estacas dor mentes e (b) tratamento de plantas em vegetação.

(a) Através do primeiro método, que se baseou na colocação de ramos dormentes dentro de estufa de ar quente a $380 \mathrm{C}$ durante $33 \mathrm{dias}$, foram submetidas a tratamento es tacas correspondentes a 51 gemas de IAC $138-22$, 78 de Itá1ia, 42 de Niagara Branca, 36 de Seibe 12 e 69 de Seyve vil1ard 5276. A porcentagem de obtenção de plantas através da enxertia das gemas sobreviventes foi em torno de $2,5 \%$, tendo resultado apenas 1 planta de IAC 138-22, 3 de Itália e 3 de Seyve Villard 5276. Todas as plantas obtidas, indexadas em Rupestris du Lot, demonstraram estar ainda infetadas pelo ví rus do mosaico das nervuras.

Não foi notada diferença entre as estacas com 1 gema ou com 2 ou mais e cobertas totalmente ou apenas nas extremidades com cera de abelha derretida com relação à manutenção da viabilidade das mesmas. Tratamentos mais prolongados resultaram em perda total da viabilidade das estacas.

(b) Adotando o método baseado na vegetação de videiras infetadas dentro de câmara a $36-380 \mathrm{C}$ para propaga ção mediante enxertia de ápices dos brotos emitidos, foram conseguidos clones sadios de 9 variedades de copa, que se achavam infetadas pelo vírus do mosaico das nervuras, isola damente ou em mistura com os vírus do enrolamento da folha, fendilhamento cortical ou ambos. As variedades foram as seguintes: Concord, IAC 138-22, IAC 457-11, Itälia, Itälia Rubi, Kio ho, Perlona, Seibel 2 e Seyve Vil1ard 5276 .

De plantas das variedades Alphonse Laval lée e Seibe1 7053, que se encontravam infetadas ao mesmo tempo pe- 
los virus do cascudo, enrolamento da folha, fendilhamento cor tical e mosaico das nervuras, foi possível eliminar 3 deles, incluindo o mosaico das nervuras; contudo, a primeira permaneceu infetada pelo vírus do fendilhamento cortical e a segunda, pelo vírus do cascudo.

Foi observado, com base em plantas das variedades Itälia, Itália Rubi e Seyve Villard 5276 , que os resul tados positivos de obtenção de material sadio foram principal mente conseguidos por enxertia de ápices de $10 \mathrm{~mm}$ coletados dos primeiros brotos emitidos, apicais ou axilares, durante - tratamento pelo calor, geralmente dentro do período aproxí mado de 60 a 90 dias. Por outro lado, notou-se que, das 6 plantas de Itālia, 4 de Itália Rubi e 3 de Seyve villard 5276 , originadas de brotos surgidos depois de 150 a 200 dias de tra tamento, apenas 1 planta de Itália Rubi encontrava-se livre do vírus do mosaico das nervuras.

Adotando a mesma técnica de tratamento pelo calor $(60$ a 90 dias a $380 \mathrm{C})$, de janeiro a março, e submetendo os ápices de cerca de 2 a $3 \mathrm{~mm} \mathrm{de} \mathrm{comprimento} \mathrm{a} \mathrm{en} \mathrm{raizamen}$ to in vitro, for am também conseguidos clones sadios das varie dades IAC 138-22, IAC 457-11, IAC 514-6, Itália, Itália Rubi, kioho, Seibe1 2 e seyve Villard 5276 . Essas videiras encontravam-se infetadas pelo vírus do mosaico das nervuras, sôs ou em combinação com os vírus do enrolamento da folha e fendilhamento cortical.

\subsubsection{Microenxertia}

Cerca de 50 segmentos de 0,5 a $0,7 \mathrm{~mm}$ contendo meristema de brotos vigorosos de plantas infetadas das va riedades Itália e Seyve Villard 5276 foram colocados em porta-enxertos também em desenvolvimento ativo, mas não houve união dos tecidos. Em todos os casos, notou-se a ocorréncia 
sistemática de escurecimento dos tecidos do microenxerto, re sultando em necrose e morte dos mesmos. Esse fenômeno manifestou-se com maior intensidade quando os āpices foram depositados em ramos jovens e suculentos de plantas de estaca; quando plantinhas de semente estioladas e mantidas in vitro foram empregadas como porta-enxertos, esse fenômeno ocorreu com menor intensidade e mais lentamente do que no primeiro caso, mas provocou a morte dos tecidos microenxertados com o passar do tempo. 


\section{DISCUSSÃO}

As evidências obtidas através da sintomatolo gia em indicadoras comprovam que o vírus do mosaico das nervuras da videira, presente nos vinhedos do Estado de São Pau lo, é idêntico ao da "grapevine fleck disease". Isso demons tra que o vírus causador foi introduzido em material propagativo infetado. Essa afirmativa também pode ser feita para as outras viroses já registradas no Brasil (KUNIYUKI, 1981), dada a semelhança sintomatológica com as existentes em outros países e dada a inexistência, até o presente, de moléstias da videira causadas por vírus autóctones no Brasil.

Nos levantamentos feitos, verificou-se que mais da metade da população das videiras cultivadas e mantidas no Estado de são paulo encontra-se infetada pelo vírus, confirmando os resultados obtidos anteriormente (KUNIYUKI \& COSTA, 1987). As variedades introduzidas apresentam porcentagem de infecção de 25 a $100 \%$. Isso pode estar correlacio nado com o nível de infecção do material propagativo introduzido. Assim, para as variedades com porcentagem de infecção de $100 \%$, é possível que o material já tivesse vindo totalmente infetado. Muito provavelmente, isso deve ter ocorrido para as variedades kioho e $01 \mathrm{impia}$; mas, neste caso, é fácil aceitar essa hipótese, uma vez que todas as suas plantas estão infetadas por isolados diferenciados que só têm si do encontrados nelas. Para as variedades que apresentam ni- 
vel de infeç̧ão abaixo de $100 \%$, é provável que o material in troduzido estivesse livre do vírus do mosaico das nervurasou menos infetado pelo vírus, somente atingindo as incidencias de monstradas em decorrência das sucessivas propagaçoes feitas durante muitos anos em São Paulo e no resto do país. São gran des as possibilidades de que o nível elevado de infecção de muitas variedades seja consequência de transmissão ocorrida no país através do emprego de porta-enxertos infetados. Isso é facilmente comprovado através de algumas variedades cria das no Instituto Agronómico de Campinas que se tornaram $100 \%$ infetadas, devido à enxertia das plantas originais sadias, re sultantes de semente, em porta-enxertos infetados, para sua multiplicação. Esse fato aconteceu no passado para as plantas de semente autofecundada ou cruzada nos trabalhos de me thoramento genético da videira no Instituto Agronómico (SAN TOS NETO, 1955). Isso mostra a importância de se proceder a multiplicação das plantas resultantes de hibridações em cava los sadios, como é feita atualmente. A constatação de que a porcentagem de infeç̧ão de certas variedades plantadas em di ferentes localidades do Estado apresentam variaçóes significativas entre regióes também pode ser explicada perfeitamente como resultantes do nível de infecção do material propaga tivo de variedades de copa e de porta-enxerto que foi introduzido nos respectivos locais. No caso das variedades Itália Rubi e Kioho Rosada (atualmente conhecida por Iguaçü Red), re sultantes de mutação somática de Itảlia e kioho, o fato de estarem $100 \%$ infetadas pelo vírus pode ser facilmente explicado nabase de que as plantas das quais se originaram os mutantes jä estavam infetadas pelo vìrus.

As plantas matrizes dos porta-enxertos revela ramestar menos infetadas do que as variedades de copa. Isso jä era esperado, pois tais videiras geralmente não săo enxer tadas para suas propagaçóes. Inicialmente, a porcentagem de infeç̧ão deve ter mostrado correlação com o nível de infec- 
Ção do material introduzido; mas, o atual nível apresentado por muitos porta-enxertos deve ter resultado principalmente da utilização de material propagativo proveniente das brotações espontâneas dos cavalos das combinaçóes enxertadas ou das plantas que se desenvolveram após a morte da copa, para reposição ou ampliação do número dessas matrizes. Foi deter minado que a incidência do vírus no material propagativo de importantes porta-enxertos utilizados pelos viticultores para ampli ação ou substituição dos vinhedos mostrou ser mais elevada do que a do material de propagação das plantas matri zes desses cavalos. Tal fato é explicável, pois os agricultores, além de obterem estacas das plantas matrizes dos porta-enxertos deseu interesse, têm o costume de conseguir material de propagação de cayalos de sua própria plantação jă estabelecida ou da de outros viticultores, da mesma região ou de outras localidades, seja de são paulo ou de outros estados vitícolas do Brasi 1. A coleta é feita de maneira indiscriminada. Assim sendo, a incidência do vírus pode elevar-se significativamente, se issoé feito em regióes onde são cultivadas variedades bastante infetadas pelo vírus. Tal fato deve ter acontecido para explicar o resultado apresenta do pelo porta-enxerto IAC 313 , pois, enquanto as plantas ma trizes mais antigas estão isentas do vírus, o material propa gativo usado na viticultura comercial encontra-se infetado com incidência muito alta.

A incidéncia do vírus demonstra ser muito ele vada nos vinhedos de outros estados brasileiros, muito provavelmente semelhante à encontrada em São Paulo. Como algumas das variedades de copa testadas foram comuns às áreas con sideradas e como são costumeiras as trocas de material propagativo entre regióes, é muito provável que diversas variedades de copa e de porta-enxerto cultivadas no Brasil tenham a mesma origem. Assimsendo, não é de se estranhar que os ví rus encontrados também sejam comuns a essas regióes vitíco- 
las. Por outro 1 ado, testes feitos em plantas de 3 varieda des de copa (Cabernet Sauvignon, Merlot e Ruby Cabernet), re sultantes de clones que haviam sido introduzidos no Rio gran de do Sul como livres dos vírus mais comuns da videira, confirmaram que elas se encontram sadias com relação ao vîrus do mosaico das nervuras e aos outros detectáveis em videiras indicadoras.

Em São Paulo, não hä risco de infecção das videiras sadias nas condiçóes de campo, pois não existem evidências de disseminação do vírus através de vetor. Caso ocor resse, a possibilidade de se encontrar plantas sadias, principalmente das variedades mais antigas, seria mínima em $10-$ cais onde a pressão de inóculo é muito alta. VuITTENEz (1978), na França, ao comentar sobre o mesmo assunto, afirma que o mosaico das nervuras é uma virose de constatação recente, de tal modo que näo existe ainda uma evidência definida sobre uma possível disseminação do vírus através de vetor. segundo esse autor, a maioria dos atuais vinhedos franceses é constituída por videiras de origem duvidosa quanto à sanidade, portanto não adequada para estudos de disseminação do vírus; o incremento do uso de material propagativo sadio poderá facilitar essas investigaçoes, submetendo as plantas a testes de indexação depois de vários anos de cultivo. para as condições de são paulo, essas consideraçôes são também válidas e interessantes, principalmente em regióes onde a incidência do vírus é elevada, como são Roque e Mairinque. Com o estabelecimento de vinhedos sadios em larga escala, é possível que a disseminação por meio de vetor venha até a ser constatada. Contudo, com base nos conhecimentos adquiridos até o presen te, é improvável que vetor eficiente seja encontrado nos vi nhedos paulistas, pelo menos dos atuais isolados do vírus do mosaico das nervuras.

Como o vírus do mosaico das nervuras e alguns 
outros que infetam a videira não têm vetor conhecido, surge a indagaçáo de como a planta primeiramente adquiriu esse ví rus. Nada é conhecido a esse respeito, mas pelo menos duas hipóteses podem ser formuladas para explicar o aparecimento desses patógenos na videira: (a) transmissão mecānica, por vetor ou por ligaçáo de cuscuta, de maneira ocasional, de certos vírus de outras espécies e (b) transmíssão mecânica, por vetor ou por ligaçáo de cuscuta, de maneira ocasional, de mutantes pertencentes a complexos de determinados vírus de outras espécies.

A introdução do vírus em videira por vetores apoia-se, dentro de certos $1 \mathrm{imites,} \mathrm{na} \mathrm{detecção} \mathrm{de} \mathrm{diversos}$ vírus com morfologia do grupo dos closterovirus em videira (GUGERLI et alii, 1984 ; MILNE et alii, 1984;, CORBETT \& WIID, 1985). Como muitos dos closterovirus conhecidos têm vetores que os disseminam na natureza (LISTER \& BAR-JOSEPH, 1981), é possível que os encontrados em videira possam representar mu tantes de alguns desses, que no passado talvez distante, foram casualmente inoculados em videira por vetores e se perpe tuaram através da propagação vegetativa. Muito provavel mente, a existência de partículas longas e flexíveis em videirascul tivadas em São paulo, que apresentam relação serológica com o yírus da tristeza dos citros (OLIVEIRA et a1ii, 1988), pode constituir-se em um exemplo que se adapta a essa hipótese.

A cuscuta comumente encontrada em cercas vivas sob condiçóes de são Paulo näo possibilitou a transmis são do vírus do mosaico das nervuras de videira infetada para a sadia. Contudo, WOODHAM \& KRAKE (1983) conseguiram resultado positivo empregando C. campestris. Uma expli cação pạ ra o resultado obtido no presente estudo pode ser apoiadana afirmativa de $\operatorname{costa~(1975)~de~que~a~espécie~comum~em~sáo~pau~}$ lo, ainda não determinada, é má transmissora de vírus, ao passo que outras espécies, como C. americanum, C. californe- 
ca, C. campestris e $C$. subinclusa são melhores para a transmissão. Essas espécies não foram empregadas, pois não se dis punha de sementes ou de material propagativo durante a época da realização dos testes. No presente estudo, o objetivo era, depois de determinada a transmissibilidade do vírus através dessa maneira, testar in úmeras espécies herbáceas pa ra encontrar aquelas capazes de mostrar sintomas. Is so seria de grande valia para os estudos de identificação do vírus e determinação do círculo de hospedeiras.

Na 1 iteratura especializada, existem relatos da observação de partículas isométricas de 23 a $30 \mathrm{~nm}$ de dịa metro em tecidos de floema de videiras infetadas pelo mosaico das nervuras (NAMBA et alii, 1979 e 1986 ; VERDEREVSKAJA et alii, 1983); há também relatos da não observação de partícu 1 as virais nos tecidos de videira infetada (CORBETT \& WIID, 1985). Assim sendo, os resultados conhecidos até o presente demonstram que, de modo geral, ainda não existe uma correlação mais evidente entre partículas observadas e sintomas do mosaico das nervuras. Em São Paulo, os exames feitos ao mi croscópio electrónico de preparaçóes de plantas de Rupestris du Lot infetadas pelo vírus do mosaico das nervuras não permitiram observar partículas isométricas e nem alongadas. Mas a tendência é considerar que o vírus seja mesmo isométrico, pois caso contrário, já teria sido detectado, não só no Brasil como em outros países.

A perpetuação do vî́rus do mosaico das nervuras através de semente não foi verificada neste estudo. Es ses resultados negativos concordam com os obtidos por HEVIN et alii (1973b); DOAZAN \& BELLEGARDE (1977) e DOAZAN (1978), que testaram sementes obtidas tanto de fecundação livre como de cruzamentos entre plantas de variedades machos e fêmeas de V. rupestris. Testes feitos no presente trabalho indicaram que a redução de vigor ou a presença de anomalias foliares 
em algumas plantas de semente não resultam de infeç̧ão virótica. Essas anomalias são interpretadas como decorrentes, principalmente da alta heterozigose apresentada por espécies de Vitis e já são conhecidas em outros países (HEVIN et alii, 1973b). A transmissäo pela semente não ocorre na epidemiologia do vírus do mosaico das nervuras e a presenfa des. te na planta não tem importância nos trabalios de melhoramen to genético da videira.. Assim sendo, plantas infetadas podem ser empregadas nos trabalhos de hibridações.

No Brasil e em outros países, as perdas causa das pelo vírus do mosaico das nervuras não são conhecidas. Era dificil fazer essas determinaçöes, uma vez que não havia clo nes sadios de variedades de importância econômica. Hoje, is so já é possível, devido á disponibilidade de material sadio, tanto de copa como de porta-enxerto.

Infecçóes mistas do vírus do mosaico das nervuras com outros vírus constatados em São Paulo são comuns em plantas de diversas variedades de copa e de porta-enxerto. Isso, contudo, não resulta em sinergismo ou outro tipo de interaçáo entre os vírus, do ponto de vista da sintomatolo gia. Mas, algumas videiras, quando infetadas por 3 ou mesmo 4 yírus ao mesmo tempo, apresentam maior reduçáo no vigor do que quando infetadas isoladamente. Nesses casos,é altamen te provável que as plantas venham a mostrar perdas até significativas n a produção.

Todas as variedades e espécies de videira estudadas comportaram-se como susceptíveis ao vírus do mosaico das nervuras. A grande maioria das videiras testadas não mos trou sintomas de palidez das nervuras decorrentes da infecfäo, embora o vírus fosse facilmente recuperado para indicado ras. Esse resultado indica que o vírus pode infetar número bem maior de variedades e espécies de Vitis. Esse conhecimen 
to amplia os já existentes, que, emsua maioria, se restrin gem às principais variedades comerciais de copa e a alguns porta-enxertos (VUITTENEZ, 1970; HEWITT et a1ii, 1972 e REFATTI \& GRANATA, 1980). O fato de a maioria das videiras não mostrar sintomas reconhecíveis demonstra a facilidade com que o vírus é perpetuado através de material propagativo infetado e explica a razão da alta incidência do patógeno no Brasi 1 .

A leitura dos testes diagnósticos do mosaico das nervuras é melhor feita nas folhas da brotação de primavera de plantas indicadoras colocadas para crescimento ao ar 1 ivre. A manutenção de indicadoras dentro de casa de vegeta ção é desfavorável para a mani festação de sintomas evidentes. Ainda não existe uma explicação comprovada para esse fato, mas é de se supor que os yidros das cas as de vegetação atuem como filtros para certos comprimentos de onda de 1 uz, interfe rindo no desenvolvimento da coloração verde das folhas de vi deira. E também possível que a temperatura, por ser mais al ta dentro de casa de vegetação, contribua para a ocorrência desse fato.

A observação de que os sintomas em indicadoras mesmo fora de casa de vegetação não se tornam vísíveis ou apa recem em poucas plantas durante períodos prolongados de muito calor pode ser atribuída a e feito da temperatura elevada. Essa interpretação se deve ao fato de que, durante esse período, as folhas jovens logo tornam-se rígidas e amareladas, principalmente de plantas náo bem estabelecidas em vasos ou mesmo, no solo. Não é fäcil demonstrar experimentalmente es se fato, mas é prováyel que assimseja, pois os sintomas po dem se manifestar em algumas plantas de crescimento vígoroso em fins de primavera ou no veräo, quando sobrevem um período de temperatura amena. A mesma explicaçáo pode ser dada para a não manifestação de sintomas embrotações ocorridas 
fora de ëpoca normal da majoria das plantas. Possivelmente, - aparecimento de sintomas nítidos quando a brotação de primavera se processa dentro de período de temperatura amena se deve ao fato de as folhas permanecerem sob condição jovem por mais tempo, desde que a palidez das nervuras menores é carac terística de folhas novas e médias. o fato de os sintomas manifestarem-se com maior intensidade em plantas com cresci mento vigoroso reforça essa hipótese.

Nenhum dos tratamentos testados foi capaz de induzir o aparecimento de sintomas fora de época normal, de maneira seme lhante à que ocorre na brotação de primavera, mes mo o baseado na colocação de plantas em câmara a $200 \mathrm{c}$, embora isso possa ocorrer em indicadoras de crescimento vigoroso no veráo, quando ocorre um período de temperatura amena. Contudo, o desenvolvimento de um método que possibilite executar os testes diagnósticos baseados nas observaçóes de outras brotaçóes além das de primavera seria de grande importân cia para a obtenção de resultados experimentais de maneira mais continuada durante o ano.

Nos vinhedos do Estado de São Paulo, jä foram reconhecidos 3 isolados do vírus do mosaico das nervuras (co mum, fraco e de kioho e olimpia), que são diferenciados atra vés de reaçóes nas videiras Golia, Kober 5 BB e Rupestris du Lot. A existência de isolados diferentes quanto aos sintomas induzidos em plantas de Rupestris du Lot jä é conhecida para o vírus do mosaico das nervuras em outros países (TRIOLO \& MATERAZZI, 1987 ).

Não há dúvidas de que os isolados presentes em plantas das yariedades kioho e olimpia cultivadas em são Pau 10 são os mesmos que ocorrem no Japão, pelos simples fato de essas videiras terem resultado de material propagativo intro duzido desse país. Isso, contudo, não significa que eles são 
semelhantes aos isolados do mosaico das nervuras associados à moléstia denominada "ajinashika", que existe nos vinhedos japoneses. Essa observação se baseia no fato de que não se dispõe de informações suficientes sobre o virus causador des sa moléstia para que se possa correlacionar com os isolados que ocorrem no Brasil. Já o isolado fraco detectado em São Paulo é originärio de uma planta da variedade Itália. Poss velmente, o seu aparecimento resultou de segregação havida a partir do complexo normal durante as propagaçóes vegetat vas feitas ao longo dos anos.

Nos testes de proteção feitos com os isolados de Kioho e olimpia e com o isolado fraco, os resultados foram um tanto inesperados. Evidência de proteção foi verificada em plantas de Kober 5 BB quando se usou como isolado pro tetor, o de kioho e olimpia e como desafiante, o isolado comum. Isso sugere que ambos os isolados pertencem a um mesmo complexo do vírus do mosaico das nervuras. Mas, ao contrário do esperado, não houve efeito de proteção, quando a premunização foi feita com o isolado fraco e a superinoculação, com os isolados comuns, tanto em Kober 5 B B como em Rupestris du Lot. Esse fato, contudo, não implica que esses isolados não sejam relacionados; o isolado fraco apenas não tem valor protetivo. Segundo costA (1975), algumas das causas que podem levar à falha na proteção são as seguintes : (a) o primeiro vírus não é bastante sistêmico, permitindo o esta belecimento do segundo nas células não invadidas pelo prime i ro; (b) o segundo tem capacidade de multiplicação muito maior do que o primeiro, vindo a sobrepujar a quantidade do prime ro, apesar da desvantagem inicial e (c) o segundo vírus pode ter maior capacidade de invasão dos tecidos meristemáticos, o que iria permitir a sua multiplicação nos tecidos não invadidos pelo primeiro, aumentando a sua vantagem nos tecidos desenvolvidos posteriormente e podendo mesmo levar à suprssão do primeiro. Plantas de kober 5 BB infetadas por iso- 
lados comuns continuaram a apresentar os sintomas, mesmo apös terem sido superinoculadas com os isolados de Kioho e $01 \mathrm{im-}$ pia, exceto em algumas, que cessaram de os apresentar. Isso indica a ocorrência do fenômeno da supressão, embora não tenha sido comprovado através de testes de recuperação do desafiante para indicadoras. Esse fenómeno é pouco frequente, mas já é conhecido para al guns vírus (BAWDEN \& KASSANIS, 1945). Esses pesquis adores acharam que o fenómeno da supres são não é semelhante ao da proteção. No caso da videira, a proteção e a supressão resultam da interação entre os mesmos isolados, ou sejam, os comuns e os de kioho e olimpia. Esse fato sugere fortemente que, pelo menos no exemplo citado, am bos os fenómenos sáo relacionados. A ocorrência de supressão pode ser explicada na base de que os isolados de kioho e $01 \mathrm{impia} t \hat{e} \mathrm{~m}$ vantagem competitiva sobre os isolados comuns, de tal modo que eyentualmente podem substituir estes últimos nos noyos crescimentos das plantas infetadas. Combase nesses resultados, pode-se até postular que em todos os casos em que uma determinada sequéncia de eventos promovida pelo segundo vírus suprime o primeiro, deve haver proteçáo quando o segundo é usado como premunizante. Esse assunto é bastante interessante para me lhor compreensão dos aspectos referen tes á etiologia do vírus e portanto, merece ser investigado com maior profundidade; mas não representa grande importân cia do ponto de vista de controle, pois o vírus, por não ter vetor, pode ser eliminado mediante obtenção de material sadio.

A diagnose segura do mosaico das nervuras não pode ser feita mediante observação de sintomas de plantas ín fetadas, mas tem que repousar no uso de videiras indicadoras. Isso porque o vírus causa infeç̧ão latente na grande maioria das variedades de copa e de porta-enxerto de importância para a viticultura de são Paulo. o porta-enxerto Rupestris du Lot é o mais indicado para ser adotado como indicado- 
ra do mosaico das nervuras em São Paulo. E capaz de reagir com sintomas distintos à infeç̧ão pelos isolados do vírus, demonstrando ser mais sensível do que os portaenxertos Golia e Kober 5BB. Além disso, apresenta a vantạ gem de jä ser indicadora do mosaico do Traviù (estirpe de "grapevine fanleaf") e do cascudo ("legno riccio" ou "grapevine stem pitting"), que ocorrem em São paulo (KUNIYUKI \& MULLER, 1987) e de alguns outros vírus assinalados em diversos países (MARTELLI, 1986). Além disso, o porta-enxerto Ru pestris du Lot é de fácil manuseio, pois apresenta porte ere to. Já o Kober 5BB, além de também ser indicadora dos isola dos comuns, serve como diferencial nos estudos de identificação dos isolados de kioho e olimpia, pois näo reage com sintomas visíveis à infecção por estes.

0 controle do mosaico das nervuras pode ser feito de modo bastante eficiente através do emprego de material propagativo sadio de variedades de copa e de porta - enxerto, dada a inexistência de um vetor do vírus causador. As sim sendo, postula-se que o material propagativo, uma vez ob tido sadio, pode ser assim mantido de maneira permanente.

Na 1 impeza de material propagativo de videira infetada através da termoterapia, o método baseado na propagação de ápices de $10 \mathrm{~mm}$ dos brotos de plantas mantidas a $380 \mathrm{C}$ durante 60 a 90 dias tem dado bons resultados (KUNIYUKI \& BETTI, 1987 e KUNIYUKI et alii, 1987). Mas foi verifica do que a manutenção das plantas sob tratamento por períodos muito prolongados ( 150 a $200 \mathrm{dias}$ ) reduz as chances de obter material livre do vírus do mosaico das nervuras. Esse fato provavelmente resulta da seleção de isolados mais resistentes ao calor do complexo do vírus. o método baseado no tratamento de estacas dormentes é impraticável para a videira, pois, além da baixíssima porcentagem de obtenção de plantas, 
a partir de gemas desses ramos tratados, não possibilita a inativação do vírus.

As tentativas de obtenção de material sadio através da microenxertia não puderam ser avaliadas, devido ao não pegamento dos enxertos. Possivelmente, isso resultou da oxidaçáo dos tecidos do cavalo da videira utilizada. AYUSo \& PE NA-IGLESIAS (1978), que adotaram essa técnica com sucesso, não mencionam a ocorrência desse fenômeno; mas como emprega ram entre-nós de ramos verdes enrijecidos e enraizados in vi tro como porta-enxerto, é provável que a oxidação tenha se manifestado com menor intensidade, ao conträrio dos ramos suculentos usados no presente trabalho.

A alternativa de se promover a importação de material propagativo sadio de variedades tradicionais é perfeitamente viável e até recomendável, se feito de países onde programas de certificação de videiras livres de vírus são desenvolvidos por instituiçóes especializadas. Contudo, é in dispensáve 1 que necessárias precauções sejam adotadas durante o processo de propagação de material introduzido como sadio. A importação resulta em considerável ganho de tempo, pois os testes de seleção por indexação e de 1 impeza, através de processos como a termoterapia, são bastante demorados. Essas operaçöes apenas se justificam para as varieda des de copa e de porta-enxerto de valor regional, cujos mate riais propagativos sadios não são disponíveis em outros países.

Já existe disponibilidade de clones livres de vírus de variedades de copa e de porta-enxerto mais importan tes para a viticultura de sáo paulo e para outras regióos ví tícolas do país. Assim sendo, as bases para o desenvolvimen to de programa visando a substituição gradativa de plantações infetadas por vinhedos sadios foram estabelecidas em Säo Pau 
10, como os que existem em muitos países (BALDACCI et alii, 1972 e 1973; VALAT, 1972; DETH, 1973; BOVEY et alii, 1974 e 1974 ; MARTELLI et alii, 1978 ; GOHEEN, 1980 ; YAMAGUCHI, 1983 ; etc.). 


\section{CONCLUSÕES}

- o vírus do mosaico das nervuras, que ocorre de maneira generalizada nos vinhedos do Estado de São Paulo, é idêntico ao causador da "grapevine fleck disease", presente na maioria dos países vitícolas;

- a perpetuação do vírus do mosaico das nervü ras através de semente é negativa e não hā evidência da exis tência de vetor nos vinhedos paulistas. A ocorrência do vírus decorre de sua perpetuação através da propagação vegetativa de plantas infetadas de variedades de copa e de portaenxerto;

- os isolados de Kioho e olimpia do vírus do mosaico das nervuras protegeram contra superinoculação com os comuns. Quando superinoculados em plantas infetadas por iso lados comuns, induziram o fenômeno da supressão em algumas instâncias;

- é postulado que um vírus, capaz de causar supressão de um anteriormente estabelecido na planta, será capaz de proteger quando primeiramente inoculado;

- o mosaico das nervuras pode ser eficientemen te controlado através do emprego de material propagativo sạ dio de variedades de copa e de porta-enxerto. 


\section{REFERÊNCIAS BIBLIOGRAFICAS}

ANUĀRIO ESTATISTICO DO BRASIL - 1986, Rio de Janeiro, 47: 282, 1987 .

AYUSO, P. \& PE ÑA-IGLESIAS, A. Microinjerto de meristemos: una nueva y prometedora técnica para regenerar vides enfermas por virus. In: CONFERENCIA INTERNACIONAL SOBRE VIRUS Y VI ROSIS DE LA VID, 6., Madrid, 1976. Anales. Madrid, INIA, 1978 . p. $319-23$.

BALDACCI, E.; BELLI, G.; FORTUSINI, A. I I Centro di Selezio ne viticola di Riccagioia. In: CONVEGNO DEL GRUPPO INTER NAZIONALE PER LO STUDIO DEI VIRUS E DELLE VIROSI DELLA VI TE, 5., Salice Terme, 1973. Rivista di Patologia Vegetale, Pavia, 9 (suppl.): 295-303, 1973 .

BALDACCI, E.; BELLI, G.; FORTUSINI, A.; OSLER, R. Selezione sanitaria della vite in Italia settentrionale: risultati e considerazioni. In : CONFERENCE DU GROUPE INTERNATIONAL D'ETUDE DES VIRUS ET DES MALADIES À VIRUS DE LA VIGNE, 4., Colmar, 1970. Annales de Phytopathologie, Paris, $72-4$ (no hors-série), 1972 . p.13-6.

BARLASS, M.; SKENE, K.G.M.; WOODHAM, R.C.; KRAKE, L.R. Re generation of virus-free grapevines using in vitro apical culture. Annals of Applied Biology, London, 101: 291-5, 1982 . 
BASS, P.; VUITTENEZ, A.; LEgIN, R. Amelioration de la the $\underline{r}$ mothérapie de la vigne par culture d'extrémités de pousses sur milieux nitritifs ou par greffage d'apex sur plan tules de semis cultivées aseptiquement in vitro. In: CoNFERENCIA INTERNACIONAL SOBRE VIRUS Y VIROSIS DE LA VID,6., Madrid, 1976. Anales. Madrid, INIA, 1978. p.325-32.

BAWDEN, F.C. \& KASSANIS, B. The suppression of one plant vi rus by another. The Annals of Applied Biology, Cambridge, $\underline{32}(1): 52-7,1945$.

BOUBALS, D. Importance économique des viroses de la vigne. Circonstances favorisant leur propagation. Lutte contre ces maladies. Bulletin de l'office International de 1 a Vigne et du vin, 44 (479): 5-39, 1971 .

BOVEY, R. Un virus latent dans le Chasselas. In: CONFERENCE DU GROUPE INTERNATIONAL D'ETUdE DES VIRUS ET DES MALADIES A VIRUS DE LA VIGNE, 4., Colmar, 1970. Annales de. Phytopathologie, Paris, 72-4 (nọ hours-série), 1972a. p. $31-4$.

BOVEY, R. Therapeutic methods applied to the grapevine. In: INTERNATIONAL HORTICULTURE CONGRESS, 18. , Te1-Aviv, 1970. Proceedings. Te1-Aviv, 1972b. Vo1. 3. p.32-8.

BOVEY, R.; BRUGGER, J.J.; SIMON, J.L.; JAQUINET, A. La sélection sanitaire de 1 a vigne en suisse romande. Revue Suisse de Viticulture, d'Arboriculture et d'Horticulture, Changins, $6: 77-83,1974$.

BOVEY, R.; GARTEL, W.; HEWITT, W.B.; MARTELLI, G.P. ; VUTTTE NEZ, A. Maladies à vírus et affections similaires de la vigne. Atlas en couleurs des symptômes- Lausanne, Ed. Payot, 1980 . $182 \mathrm{p}$. 
BOVEY, R.; ROCHAIX, M.; SIMON, J.L. Résultats et perspectives d'avenir de la sélection sanitaire de la vigne. Revue Suisse de Viticulture, d'Arboriculture et d'Horticulture, Changins, 7: 161-6, 1975 .

CADMAN, C.F.; DIAS, H.F.; HARRISON, B.D. Sap-transmissible viruses associated with diseases of grapevine in Europe and North America. Nature, London, 187: 577-9, 1960.

CORBETT, M.K. \& WIID, J. Closterovirus-like particles in extracts from diseased grapevines. Phytopathologia, Mediterranea, Bologna, 24: 91-100, 1985 .

Costa, A.S. Proteção. In: Virologia Vegetal. Curso de Pósgraduação em Fitopatologia, ESALQ/USP. Campinas, 1975. $15 \mathrm{p}$.

DETin, P.S. The New York State grape certification program. New York's Food Life Sciences Quarterly, Ithaca, 6 (4): 5,1973 .

DIAS, H.F. Mechanical transmission of viruses to herbaceous hosts. In: INTERNATIONAL CONFERENCE ON VIRUS AND VECTOR ON PERENNIAL HOSTS, WITH SPECIAL REFERENCE TO Vitis, Davis, 1965. Proceedings. Davis, University of California, Department of Plant Pathology, 1965. p.235-47.

DOAZAN, J.P. On the seed-transmission of some grapevine vi rus diseases. In: CONFERENCIA INTERNACIONAL SOBRE VIRUS Y VIROSIS DE LA VID, 6., Madrid, 1976. Anales. Madrid, INIA, 1978 . p. $83-5$.

DOAZAN, J.P. \& BELLEGARDE, H. Essai de transmission par la graine de viroses de la vi gne (court-noué, marbrure). Annales de Amélioration de plantas, Paris, $27(2): 245-53$, 1977. 
ENGELBRECHT, D.J. \& NEL, A.C. A graft-transmissible stemgrooving of grapevine in the western Cape Provincia (South Africa) resembling legno riccio... Phytophylactica, Pretoria, $3: 93-6,1971$.

GOHEEN, A.C. Virus and viruslike diseases of grapes. HortScience, Alexandria, $12: 465-9,1977$.

GOHEEN, A.C. The California clean grape stock program. Ca1ifornia Agriculture, Berkeley, $34(7): 15-6$, jul. 1980 .

GOHEEN, A.C. \& LUHN, C.F. Heat inactivation of viruses in grapevines. In: CONVEGNO DEL GRUPPO INTERNAZIONALE PER LO STUDIO DEI VIRUS E DELLE VIROSI DELLA VITE, 5., S alice Terme, 1973 . Rivista di Patologiavegetale, Pavia, 9 $(\mathrm{supp} 1):. 287-9, \quad 1973$.

GOHEEN, A.C.; LUHN, C.F.; HEWITT, W.B. Inactivation of grapevine viruses in vivo. In: INTERNATIONAL CONFERENCE ON VIRUS AND VECTOR ON PERENNIAL HOSTS, WITH SPECIAL REFEREN CE To Vitis, Dávis, 1965 . Proceedings. Davis, University of California, Department of Plant Pathology, 1965. p. $255-65$.

GUGERLI, P. ; BRUGGER, J.J. ; BOVEY, R. L'tenroulement de 1 a vigne: mise en évidence de particules virales et développement d'une méthode immuno-enzymatique pour le diagnostic rapide. Revue Suisse de Viticulture, d'Arboriculture et d'Horticulture, Changins, $16(5): 299-304,1984$.

GUIRADO, N.; MULLER, G.W.; BETTI, J.A.; PRATES, H.S. Manifes tação rápida de sintomas foliares do vírus da sorose dos citros em ambiente refrigerado. Fitopatologia Brasileira, Brasília, $11(2)$ : 181 , jun. 1986 . 
HEVIN, M.; LECLAIR, P.; RIVES, M. Green-grafting as quick and secure method for graft-indexing viruses in the grape vine. In: CONVEGNO DEL GRUPPO INTERNAZIONALE PER LO STUDiO DEI VIRUS E DELlE VIROSI DELla VITE, 5., Salice Terme, 1973. Rivista di Patologia Vegetale, Pavia, 9 (supp1.): $277-8, \quad 1973 a$.

HEVIN, M.; OTTENWAELTER, M.M.; DOAZAN, J.P.; RIVES, M. Investigating the transmission of marbrure and fanleaf through the seed in the grapevine. In: CONVEGNO DEL GRUPPO INTERNAZ I ONALE PER LO STUDIO DEI VIRUS E DELLE VIROSI DELLA VITE, 5., Salice Terme, 1973. Rivista di Patologia Vegetale, Pavia, 9 (suppl.):253-8, $1973 \mathrm{~b}$.

HEWITT, W.B. Viruses and virus diseases of the grapevine. Review of Applied Mycology, London, 47: 433-55, 1968.

HEWITT, W.B. On the origin and distribution of vitis and the virus diseases of the grapevine. In: CONFERENCIA INTERNACIONAL SOBRE VIRUS Y VIROSIS DE LA VID, 6., Madrid, 1976. Anales. Madrid, INIA, 1978 . P.3-5.

HEWITT, W.B.; GOHEEN, A.C.; CORY, L.; LUHN, C.F. Grapevine fleck disease, latent in many varieties, is transmitted by graft-inoculation. In: CONEERENCE DU GROUPE INTERNATIONAL D'ETUDE DES VIRUS ET DES MALADIES À VIRUS DE LA VIGNE, COImar, 1970. Annales de Phytopathologie, Paris, $72-4$ (no hors-série), 1972. p.43-7.

HEWITT, W.B.; GOHEEN, A.C.; RASKI, D.J.; GOODING JR., G. V. studies on virus diseases of the grapevine in California. Vitis, Landau (Pfalz), $3: 57-83,1962$. 
HUGlin, P.; GUillot, P.; VAlat, C.; VUittenez, A. L'évaluation génétique et sanitaire du matérial clonal de la vigne. Bulletin de $l^{\prime}$ office International de 1 a Vigne et du Vin, Paris, 53(597): 857-82, 1980 .

INFORMAÇÕES ECONOMICAS 3/88, São Paulo, 18: 35-48, 1988.

KAHN, R.P.; WATERWORTH, H.E.; GILLASPIE JR., A.G.; FOSTER, J.A.; GOHEEN, A.C.; MONROE, R.L.; POVICH, W.L.; MOCK, R. G.; LUHN, C.F.; CALAVAN, E.C.; ROISTACHER, C.N. Detection of viruses or virus-like agents in vegetatively propagated plant importations under quarantine in the United States, 1968-1978. Plant Disease Reporter, Beltsville, 63: 775$9, \quad 1979$.

KRAKE, L.R. \& WOODHAM, R.C. Grapevine summer mottle: a new graft-transmissible disease. Vitis, Landau (Pfalz): 17: $266-70,1978$.

KUNIYUKI, H. Ocorrência do mosaico das nervuras da videira (grapevinefleck disease) em São Paulo. Revistada Sociedade Brasileira de Fitopatologia, Campinas, 9 : 39 , 1976 (Resumo).

KUNIYUKI, H. Viroses da videira no Brasil. Fitopatologia Bra sileira, Brasília, 6 $(2): 300-1$, jun. 1981.

KUNIYUKI, H. \& BETTI, J.A. Obtenção de clones isentos de vírus de videira através da termoterapia em são paulo. Summa Phytopathologica, Jaguariūna, 13(3/4): 173-84, ju1/ Dez. 1987 .

KUNIYUKI, H. \& COSTA, A.S. Incidência de vírus da videira em São Paulo. Fitopatologia Brasileira, Brasília, 12 (3): $240-5$, set. 1987 . 
KUNIYUKI, H. \& MULLER, G.W. Diagnose do cascudo da videira em São Paulo. Summa Phytopathologica, Piracicaba, 13 (1) $2): 26$, jan./jun. 1987.

KUNIYUKI, H.; MULLER, G.W.; BETTI, J.A. Eliminação de vĩrus em videira através da termoterapia associada a propagação de aṕices caulinares por enraizamento in vitro. In: conGRESSO BRASILEIRO DE FRUTICULTURA, 9., Campinas, 22-27 nov. 1987. Resumos. p. $71-2$.

LEGIN, R. Expérimentation pour étudier $1^{\prime}$ effect des princí pales viroses sur la végetation et la production de la vigne. In: CONFERENCE DU GROUPE INTERNATIONAL D'ETUDE DES VIRUS ET DES MALADIES A VIRUS DE LA VIGNE, 4., , COImar, 19.70. Annales de Phytopathologie, Paris, $72-4$ (n9 hors-série), 1972 . p.49-57.

LEGIN, R. \& VUITTENEZ, A. Comparaíson des symptômes et trans mission par greffage d'une mosaique nervaire de Vitis vinifera, de 1 a marbrure de $V$. rupestris et d'une affection nécrotique des nervures de 1'hybride Rup.-Ber1. 110R. In: CONVEGNO DEL GRUPPO INTERNAZIONALE PER LO STUDIO DET VIRUS E DELLE VIROSI DELLA VITE, 5., Salice Terme, 1973. Rivista di Patologia Vegetale, Pavia, 9 (suppl.): 57-63, 1973 .

LISTER, R.M. \& BAR-JOSEPH, M. Closterovirus. In: KURSTAK, ed, Handbook of plant virus infections and comparative diagnosis. Elsevier, North-Holland Biomedical Press, 1981. Part IV, Cap. $24 . \quad \mathrm{p} .809-44$.

MARTELLI, G.P. Virus and virus-1ike diseases of the grapevine in the Mediterranean area. FAO Plant Protection Bul. letin, Roma, $34: 25-42,1986$. 
MARTElli, G.P.; SAVINo, V.; ROSCIGlione, B.; QUACQUARElli, A. Clonal and sanitary selection and production of virus disease-free grapes in Southern Italy. In: CONFERENCIA INTERNACIONAL SOBRE VIRUS Y VIROSIS DE LA VID, 6., Madrid, 1976. Anales. Madrid, INIA, 1978. p.151-66.

MCGECHAN, J.K. Important virus diseases of grapevines in New South Wales. Agricultural Gazette of New South Wales, Rydalmere, $81: 349-52,1970$.

MILNE, R.G.; CONTI, M.; LESEMANN, D.E., STELLMACH, G. ; TANNE, E.; COHEN, J. Closterovirus-1ike particles of two types associated with diseased grapevines. Phytopatologische Zeitschrift, Berlin, $110: 360-8,1984$.

MINK, G.J. \& PARSONS, J.L. Procedures for rapid detection of virus and viruslike diseases. Plant Disease Reporter, Be 1 tsvi $11 \mathrm{e}, 61(7): 567-71, \quad 1977$.

MURASHIGE, T.\& \& SKOOG, F. A revised medium for rapid growth and bioassays with tobacco tissue cultures. Physiologia Plantarum, Copenhagen, $15: 473-97,1962$.

NAMBA, S.; IWANAMI, T.; YAMASHITA, S.; DOI, Y.; HATAMOTO, M. Three phloem-limited viruses of grapevine: direct fluorescent detection. In: PLANT VIRUS DISEASES OF HORTICULTURAL CROPS IN THE TROPICS AND SUBTROPICS, Taipei, 1986. Taipei, Food and Fertilizer Technology Center, 1986. p. 109-26. Apud Review of Plant Pathology, Farnham Royal, $66(5): 215,1987$. (Resumo).

NAMBA, S.; YAMASHITA, S.; DOI, Y.; YORA, K. A small s pherical virus associated with the ajinashika disease of koshu grapevine. Annals of the Phytopathological Society of Ja pan, Tokyo, $45(1): 70-3$, Jan. 1979 . 
NEL, A.C. \& ENGELBRECHT, D.J. Grapevine virus diseases in South Africa and the influence of latent viruses in the nursery. In: CONFERENCE DU GROUPE INTERNATIONAL D'ETUDE DES VIRUS ET DES MALAdies A VIRUS DE LA VIgNE, 4., Colmar, 1970. Annales de Phytopathologie, Paris, 72-4 (no hors-série), 1972 . p.67-74.

OJIMA, M.; RIGITANO, O.; CAMPO DALLORTO, F.A.; BARBOSA, W.; RIBEIRO, I.J.A.; TERRA, M.M.; AMARO, A.A.; BILLER, V.S. P.; BETTI, J.A.; KUNIYUKI, H . ; MARTINS, F.P., SCARANARI, H.; FAHL, J.I. Fruticultura de Clima Temperado no Estado de são paulo: diagnóstico da situação e conômica e cultú ral e atividades de pesquisa no Instituto Agronómico de Campinas. Boletim Técnico. Campinas, Instituto Agronômí co, no $89,1984 ., 72$ p.

OLIVEIRA, A.R.; VEGA, J.; KUNIYUKI, H.; BAPTISTA, C.R. ; MUL LER, G.W.; COSTA, A.S. Deteç̧̃o de vírus se rologicamen te idêntico ao da tristeza dos citros em calos de videira Seibel 2 com enrolamento da folha através de MEIAD. Fitopatologia Brasileira, Brasília, $13(2)$ : 133, jul. 1988 . (Resumo).

OTTENWAELTER, M.M.; HEVIN, M.; LECLAIR, P.; DOAZAN, J.P., RI VES, M. Heat-therapy eliminates the ability to transmit the causal agent of "marbrure" in several V. vinifera clo nes and in $V$. rupestris du Lot ( $\mathrm{St}$. George). In: CONVEGNO DEL GRUPPO INTERNAZIONALE PER LO STUDIO DEI VIRUS E DELLE VIROSI DELLA VITE, 5,, Salice Terme, 1973, Rivista__di Patologia Vegetale, Pavia, $\underline{9}$ (supp1.): $281-5,1973$.

PEDROSO, E.I. Deteç̧ão e caracterização de agentes causais de viroses e doenças afins, no âmbito da seleção sanitária da videi ra em Portuga1. Lisboa, 1987. 213p. (Doutorado - Instituto Superior de Agricultura/Universidade Técnica de Lisboa). 
PEN NA-INGLESIAS, A. Consideraciones sobre la problematica de los virus de la vid. In: CONFERENCIA INTERNACIONAL SOBRE VIRUS Y VIROSIS DE LA VID, 6., Madrid, 1976. Anales. Madrid, INIA, 1978. p.IX-XLVII.

PE NA-INGLESIAS, A. \& AYUSO, P. Further research on the detection of grapevine viruses in spain. In: ConvEGNO DEL GRUPPO INTERNAZIONALE PER LO STUDIO DEI VIRUS E DELLE VIROSI DELLA VITE, 5., Salice Terme, 1973. Rivista di Patologia Vegetale, Pavia, 9 (supp1.): 28-30, 1973 .

PEREIRA, F.M. \& MARTINS, F.P. Instruçöes para a cultura da videira. Boletim, Campinas, Instituto Agronómico, no $199,1972.48 \mathrm{p}$.

PROGNÓSTICO $1987 / 88$, São Paulo, 16: $18,1987$.

REFATTI, E. \& GRANATA, G. Distribution of fleck disease in Sicily and reactions on some indicators to its agent. In: MEETING OF THE INTERNATIONAL COUNCIL FOR THE STUDY OF VIRUS AND VI RUS -LIKE DISEASES OF THE GRAPEVINE, 7., Niagara Falls, 1980. Proceedings. Niagara Fa11s, Agriculture Canada, 1980. p. $35-9$.

REFATTI, E.; GRANATA, G.; GRASSO, S. On small vein mosaic virus. In: CONFERENCIA INTERNACIONAL SOBRE VIRUS Y VIROSIS DE LA VID, 6., Madrid, 1976. Anales, Madrid, INIA, 1978. P. $197-201$.

RIVES, M. Séparation de la marbrure et du court-noué (panachure) chez la vigne par thermothérapie. In: CONFÉRENCE DU GROUPE INTERNATIONAL D'ETUDE DES VIRUS ET DES MALADIES Á VIRUS DE LA VIGNE, 4., Colmar, 1970. Annales de Phytopathologie, Paris, 72-4 (no hors-série), 1972. p.75-7. 
SANTOS NETO, J.R.A. Melhoramento da videira. Bragantia, Cam pinas, 14: 237-58, 1955 .

SANTOS NETO, J.R.A. A cultura da videira. OAgronómico, Cam pinas, $21: 67-108,1969$.

SHTERENBERG, P.M.; MILKUS, B.N.; BEREZOVSKAYA, E.A., On the composition, distribuion and harmfulness of virus diseasses of grapevine in Ukraina. In: CONVEGNO DEL GRUPPO INTERNAZIONALE PER LO STUDIO DEI VIRUS E DELLE VIROSI DELLA VITE, 5., Salice Terme, 1973. Rivista di Patologia Vegele, Pavia, $\underline{9}$ (supp1.): 23-7, 1973 .

TERAI, Y \& \& YANO, R. Ajinashika disease of the grapevine dultivar Koshu in Japan. In: MEETING OF THE INTERNATIONAL COUNCIL FOR THE STUDY OF VIRUS AND VIRUS-LIKE DISEASES OF THE GRAPEVINE, 7, , N iagara Fa $11 \mathrm{~s}$, 1980. Proceedings. Niagara Falls, Agriculture Canada, $1980 . \quad$ P. $15-9$.

TERAI, Y. \& YANO, R. Effect of grapevine leafroll grapevine fleck viruses on sugar content of grapes. Bulletin of the Yamanashi Fruit Experiment Station, Manriki, 6: 95-9, 1985 .

TRIOLO, E. \& RESTA, E. The responses of the grapevine fleck agent to tetracycline-HCl antibiotic and Dienes's stain. Phytopathologia Mediterranea, Bologna, 24(1/2): $197-203$, 1985 .

TRIOLO, E. \& MATERAZZI, A. La "maculatura infettiva" della vite: influenza di isolati diversi sull'attitudine alla propagazione vegetativa di Vitis rupestris "st. George". La Recherche Agronomique in Suisse, $26(3): 320-4,1987$. 
UYEMOTO, J.K.; MARTELLI, G.P.; WOODHAM, R.L.; GOHEEN, A.C.; DIAS, H.F. Grapevine (Vitis) virus and virus-Iike diseases. In: BARNETT, O.W. \& TOLIN, S.A. Plant Virus SIide Series. Clemson, Clemson University, 1978. Set. no 1. $29 \mathrm{p}$.

VALAT, C. Note concernant les travaux de séléction sanitaire conduits par 1'Association Nationale Technique pour 1 'Amélioration de la Viticulture. In: CONFERENCE DU GROU PE INTERNATIONAL D'ETUDE DÉS VIRUS ET DES MALADIES À VIRUS DE LA VIGNE, 4., Colmar, 1970. Annales de Phytopatho 1ogie, paris, 72-4 (no hors - série), 1972. p.89-94.

VALAT, G.; GRENAN, S.; AURAN, G.; BONNET, A. Guérison de quelques maladies à virus de 1 a vigne par thermotherápie de plantules cultivées in vitro. Vigneset Vins, Paris, 284: $19-22$, 1979 .

VERDEREVSKAJA, T.D.; MARINESKU, V.G.; SEMTSCHIK, E.S. Aetiology and diagnosis of grapevine fleck. Arch. fUr Phytopathologie un Pflanzenschutz. $19(4): 222-6,1983$. Apud Review of Plant Pathology, Farnham Royal, 63(6): 230 , 1984. (Resumo)

VUITTENEZ, A. Observations sur une mosaique de 1 a vigne, pro bablement independent du virus du court-noué. Annales de Epiphyties. "Etudes de Virologie", Paris, 17: 67-73, 1966.

VUITTENEZ, A. Méthodes de diagnostic des viroses de 1 a vigne. Bulletin de $1^{\prime}$ office International de $1 \mathrm{a}$ Vigne et du Vin, Paris, $43(475): 926-43,1970$. 
VUITtEnEZ, A. Méthodes of studying virus diseases of grapevines. In: CONVEGNO DEL GRUPPO INTERNAZIONALE PER LO STU DIO DEI VIRUS E DELLE VIROSI DELLA VITE, 5., Salice Terme, 1973. Rivista di patologia Vegetale, Pavia, 9 (suppl.): $123-31,1973$.

VUITTENEZ, A. Suspected virus diseases of the grapevine. In: CONFERENCIA INTERNACIONAL SOBRE VIRUS Y VIROSIS DE LA VID, 6., Madrid, 1976. Anales. Madrid, INIA, 1978. p.151-61.

WATANABE, Y.; YAMASHITA, H.; IKAWA, Y, Quick detection of grapevine fleck by green-grafting. Research Bulletin of Plant Protection Seryice, Tokyo, 22: $101-3,1986$. Apud Review of Plant Pathology, Farnham Royal, $66(5): \quad 215$, 1987. (Res umo)

WOODHAM, R.C. \& KRAKE, L.R. Inyestigations on transmission of grapevine leafroll, yellow speckle and fleck diseases by dodder. Phytopathologische Zeitschrift, Berlin, 106 : $193-8, \quad 1983$.

WOODHAM, R.C.; TAYLOR, R.H.; KRAKE, L.R. Grapevine virus and virus-1ike diseases in Southern Australia. In: CONVEGNO DEL GRUPPO INTERNAZIONALE PER LO STUDIO DEI VIRUS E DELLE VIROSI DELLA VITE, 5,, salice Terme, 1973, Rivista a di Patologia Vegetale, Pavia, 9 (supp1.): 17-22, 1973.

YAMAGUCHI, A. Virus certification of fruit trees. in Japan. Japan Agricultural Research Quarterly, Tokyo, $17(3): 180$ $-4,1983$.

YUKI, V.A.; MULLER, G.W.; COSTA, A.S. Inativação do vírus da tristeza em estacas de 1 imão tahiti, por termoterapia. In: CONGRESSO BRASILEIRO DE FRITICULTURA, 2,, Vi çosa-Be 10 Horizonte, 1973. Anais. Viçosa-Belo Horizonte, 1973. Vo 1. I. P. $201-9$. 